\title{
Article \\ ClbG in Avian Pathogenic Escherichia coli Contributes to Meningitis Development in a Mouse Model
}

\author{
Peili Wang 1,2, Jiaxiang Zhang ${ }^{1,2}$, Yanfei Chen ${ }^{1,2}$, Haoran Zhong ${ }^{1,2}$, Heng Wang ${ }^{1,2}$, Jianji Li ${ }^{1,2}$, Guoqiang Zhu ${ }^{1,2}$, \\ Pengpeng Xia ${ }^{1,2} \mathbb{D}$, Luying Cui ${ }^{1,2}$, Jun $\mathrm{Li}^{1,2}$, Junsheng Dong ${ }^{1,2}$, Qingqing Gao ${ }^{1,2}$ and Xia Meng ${ }^{1,2, *}$ \\ 1 College of Veterinary Medicine, Yangzhou University, Yangzhou 225009, China; \\ wangpeilino1@sina.com (P.W.); jiaxiangzh_ang@sina.cn (J.Z.); chenmanbuzhidao@sina.cn (Y.C.); \\ zhongaoran123@sina.cn (H.Z.); wh@yzu.edu.cn (H.W.); jjli@yzu.edu.cn (J.L.); yzgqzhu@yzu.edu.cn (G.Z.); \\ ppxia@yzu.edu.cn (P.X.); lycui@yzu.edu.cn (L.C.); ydjunli@sina.cn (J.L.); 007601@yzu.edu.cn (J.D.); \\ qqgao@yzu.edu.cn (Q.G.) \\ 2 Jiangsu Co-Innovation Center for Prevention and Control of Important Animal Infectious Diseases and \\ Zoonoses, Yangzhou 225009, China \\ * Correspondence: mengxia_1@126.com
}

Citation: Wang, P.; Zhang, J.; Chen, Y.; Zhong, H.; Wang, H.; Li, J.; Zhu, G.; Xia, P.; Cui, L.; Li, J.; et al. ClbG in Avian Pathogenic Escherichia coli Contributes to Meningitis Development in a Mouse Model. Toxins 2021, 13, 546. https:// doi.org/10.3390/toxins13080546

Received: 14 June 2021

Accepted: 2 August 2021

Published: 6 August 2021

Publisher's Note: MDPI stays neutral with regard to jurisdictional claims in published maps and institutional affiliations.

Copyright: (C) 2021 by the authors. Licensee MDPI, Basel, Switzerland. This article is an open access article distributed under the terms and conditions of the Creative Commons Attribution (CC BY) license (https:// creativecommons.org/licenses/by/ $4.0 /)$.

\begin{abstract}
Colibactin is a complex secondary metabolite that leads to genotoxicity that interferes with the eukaryotic cell cycle. It plays an important role in many diseases, including neonatal mouse sepsis and meningitis. Avian pathogenic Escherichia coli (APEC) is responsible for several diseases in the poultry industry and may threaten human health due to its potential zoonosis. In this study, we confirmed that $c l b G$ was necessary for the APEC XM strain to produce colibactin. The deletion of $c l b G$ on APEC XM contributed to lowered $\gamma \mathrm{H} 2 \mathrm{AX}$ expression, no megalocytosis, and no cell cycle arrest in vitro. None of the 4-week Institute of Cancer Research mice infected with the APEC XM $\Delta c l b G$ contracted meningitis or displayed weakened clinical symptoms. Fewer histopathological lesions were observed in the APEC XM $\Delta c l b G$ group. The bacterial colonization of tissues and the relative expression of cytokines $(I L-1 \beta, I L-6$, and TNF- $\alpha)$ in the brains decreased significantly in the APEC XM $\triangle c l b G$ group compared to those in the APEC XM group. The tight junction proteins (claudin-5, occludin, and ZO-1) were not significantly destroyed in APEC XM $\triangle c l b G$ group in vivo and in vitro. In conclusion, $c l b G$ is necessary for the synthesis of the genotoxin colibactin and affects the development of APEC meningitis in mice.
\end{abstract}

Keywords: colibactin; clbG; Escherichia coli meningitis; APEC

Key Contribution: $c l b G$ is necessary for the synthesis of the genotoxin colibactin; which is strongly related to the meningitis induced by APEC XM. This is the first study to demonstrate the direct pathogenicity of $c l b G$ in vivo.

\section{Introduction}

In 2006, colibactin was identified in a neonatal meningitis E. coli (NMEC) strain (IHE3034) by Nougayrède and colleagues [1]. Colibactin is a natural and genotoxic chemical compound, which is synthesized by a hybrid non-ribosomal peptide synthetase-polyketide synthase (NRPS-PKS) assembly line encoded by the $p k s$ genomic island. E. coli, Citrobacter koseri, Klebsiella pneumoniae, and Klebsiella aerogenes harbor this pks genomic island [2]. The $p k s$ island contains 19 genes ( $c l b A$ to $c l b S)$, including phosphopantetheinyl transferase $(c l b A)$, the nonribosomal peptide synthetases $(c l b N$ and $c l b B)$, freestanding acyltransferase $(c l b G)$, prodrug transporter $(c l b M)$, and colibactin-maturing peptidase $(c l b P)$. Colibactin has been proven to be related to mammalian cell DNA double-strand breaks (DSBs), chromosome aberrations, and cell cycle arrest in the G2/M phase [1,3]. Our previous work found expression of many genes in $p k s$ island changed when avian pathogenic E. coli (APEC) XM strain infected the bEnd.3 cells [4]. However, most studies of colibactin just focused 
on cell senescence [5], intestinal homeostasis regulation [6], tumor microenvironment modification [7], and colon tumor growth [8] and limited studies have been undertaken regarding meningitis. Therefore, this study aimed to achieve a better understanding of the contributions of colibactin to $E$. coli in the process of meningitis.

APEC is an important member of the extraintestinal pathogenic E. coli (ExPEC) group. APEC causes severe acute systemic disease and leads to extensive economic losses in poultry industries. NMEC is another member of the ExPEC group, and it is the predominant Gram-negative bacterial pathogen associated with meningitis in newborn infants that accounts for high mortality and morbidity rates $[9,10]$. Increasing evidence indicates that ExPEC infection is more likely linked to the phylogenetic background of one strain than to its ecological background [11,12]. A majority of NMEC $[13,14]$ and highly virulent strains of APEC $[15,16]$ belong to the phylogenetic group B2. In addition, APEC has a broad range of virulence factors, similar to NMEC strains, including outer membrane protein A (OmpA), type I fimbriae (FimH) [17], and ferric aerobactin receptor (IutA) [18], which give APEC more fitness and pathogenic advantages in mammals. Previous studies demonstrated that APEC can cause bacteremia, sepsis, and meningitis in neonatal rats or mice $[19,20]$. ExPEC strains isolated from humans and fowl have a high genetic similarity, and some of them can be transmitted between humans and avians [21,22]. Due to the high plasticity of the E. coli genome, APEC strains are speculated as an armory of NMEC and have the ability to be potential zoonotic bacteria.

The colibactin-producing bacteria could profoundly affect their host's health. The rates of $\mathrm{pks}^{+}$E. coli isolated from healthy neonates' stools [23] or grown-up guts [24] are lower than $35 \%$. However, the percentages of $p k s^{+} E$. coli increased noticeably in extraintestinal infections, such as urinary tract infection [25], sepsis, pneumonia, and neonatal meningitis [26]. Pks island is strongly associated with E. coli of phylogroup B2 [2,23], which is the most common phylogroup of NMEC $(67.92-78.8 \%)[27,28]$ and is related to the high pathogenicity of APEC $[15,16]$. The rate of E. coli carrying $p k s$ islands is also frequently associated with many important virulence factors for meningitis, such as adhesins, hemolysins, toxins, and siderophores [2]. In previous studies, colibactin could induce apoptosis of $\mathrm{T}$ lymphocytes, and has been involved in systemic infection and meningitis in mouse models [29]. A pks ${ }^{+}$K. pneumoniae infected BALB/c mouse model showed that colibactin played a key role in pathogenic steps toward the development of meningitis [30]. However, the contribution of colibactin to E. coli meningitis is still unknown. As the mature colibactin is still difficult to extract or purify from bacteria to date [31], it is difficult to investigate the role of pure colibactin in meningitis development. $c l b G$ belongs to the $p k s$ island and is the only component to recognize the aminomalonylacyl carrier protein (AM-ACP) extender unit and transfer it to multiple polyketide synthase (PKS) modules [32]. In this study, we deleted the $c l b G$ gene to reduce colibactin production in APEC XM, and established a meningitis mouse model to find out the contribution of $c l b G$ in the synthesis of colibactin and the development of meningitis.

\section{Results}

\subsection{Genetic Stability and Growth Curves of the Deletion and Complemented Mutants}

The deletion (APEC XM $\Delta c l b G$ ) and complemented (APEC XM $\Delta c l b G / p c l b G$ ) mutants were successfully constructed (Figure 1A). DNA sequencing identified APEC XM $\Delta c l b G$ and APEC XM $\triangle c l b G / p c l b G$ without any spurious mutation after 30 generations. The growths of the deletion and complemented mutants were similar to that of APEC XM in the LB broth media (Figure 1B). The result supported the fact that the deletion of $c l b G$ did not affect the growth rate. 
(A)

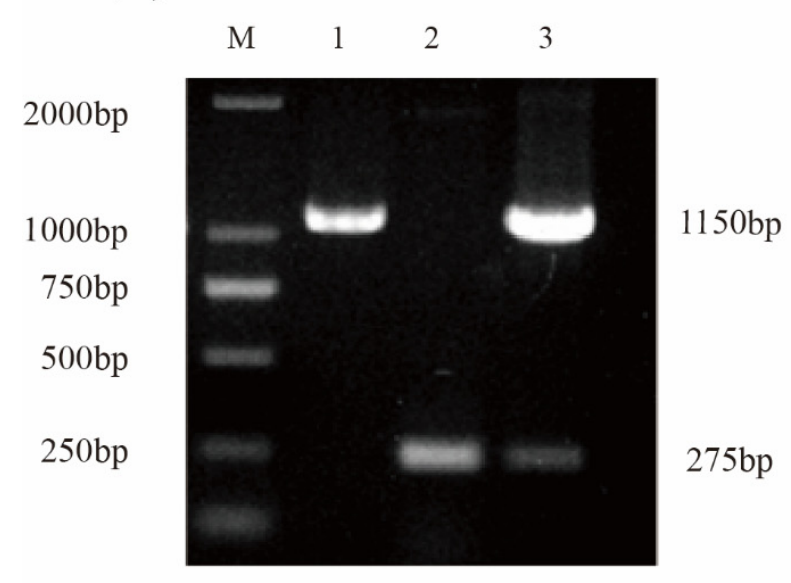

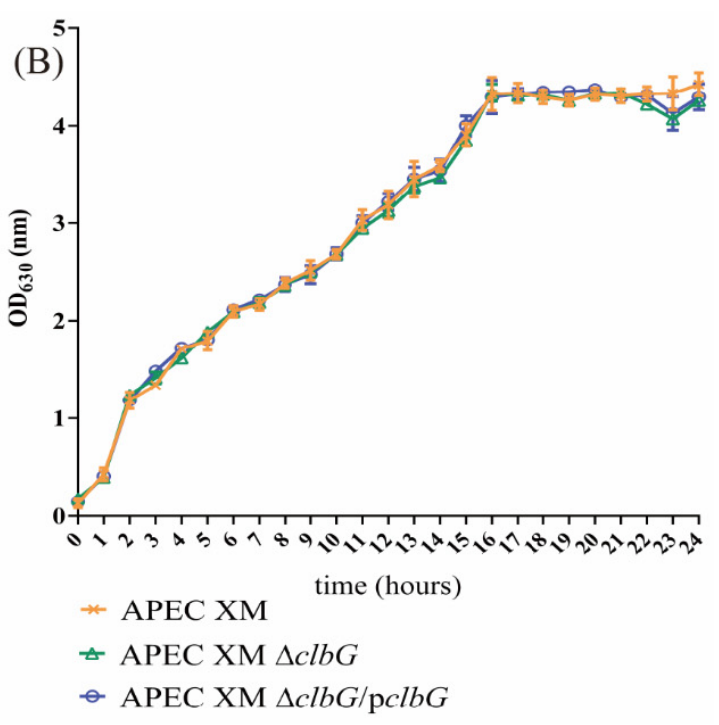

Figure 1. Verification of mutants and the ability of reproduction. (A) Identification of mutants by PCR. The avian pathogenic Escherichia coli (APEC) XM, APEC XM $\Delta c l b G$, and APEC XM $\Delta c l b G / p c l b G$ were amplified with primer P1/P2. (Lane M, DNA molecular size marker; Lane 1, APEC XM; Lane 2, APEC XM $\Delta c l b G$; and Lane 3, APEC XM $\Delta c l b G /$ pclbG) (B) Growth curves of bacteria. APEC XM, APEC XM $\Delta c l b G$, and APEC XM $\Delta c l b G / p c l b G$ were grown in LB broth at $37^{\circ} \mathrm{C}$ under aerobic conditions. The absorbance of culture at $\mathrm{OD}_{630}$ was measured per hour. The growth curves were presented as the mean \pm standard errors of the mean for three independent experiments. There was no difference in growth between the three strains.

\subsection{Deletion of clbG Affects the Colibactin Production of Avian Pathogenic Escherichia coli (APEC) XM}

To confirm the role of $c l b G$ during the colibactin biosynthesis process, we detected the $\gamma \mathrm{H} 2 \mathrm{AX}$ expression, megalocytosis level, and cell cycle phases in infected bEnd.3 cells to quantify the colibactin production of each strain. Colibactin induces an increase in $\gamma \mathrm{H} 2 \mathrm{AX}$ expression of infected cells due to DSBs. The immunofluorescence staining assay of $\gamma \mathrm{H} 2 \mathrm{AX}$ was used to measure the level of DSBs in bEnd.3 cells. After $4 \mathrm{~h}$ of infection, the percentages of $\gamma \mathrm{H} 2 \mathrm{AX}$ positive cells in the APEC XM group and the APEC XM $\Delta c l b G / p c l b G$ group increased significantly at $0 \mathrm{~h}$ post-incubation (hpi, Figure 2A,B) and 72 hpi (Figure 2C,D), compared with those in the control group. There was no difference between the APEC XM $\triangle c l b G$ group and the control group at 0 hpi and $72 \mathrm{hpi}$.

Meanwhile, colibactin led to a progressive enlargement of bEnd.3 cell body and nucleus due to blocking of the cell cycle. The absorbance values of methylene blue staining cells at $630 \mathrm{~nm}$ were used to quantify the cytotoxicity. As expected, the cells infected by AEPC XM and APEC XM $\triangle c l b G / p c l b G$ showed similar enhanced megalocytosis (Figure 2E) and significantly lower absorbance $(630 \mathrm{~nm})$ (Figure $2 \mathrm{~F})$, compared with the control group. The cells infected with APEC XM $\triangle c l b G$ displayed a normal cell morphology and a similar absorbance as the control group. When the DNA damage was beyond repair, cells underwent cycle arrest at G2/M. The cell cycle analysis was tested by flow cytometry. As shown in Figure 2G,H, the APEC XM and APEC XM $\Delta c l b G / p c l b G$ resulted in G2/M phase accumulation in bEnd.3 cells. APEC XM $\triangle c l b G$ did not induce cell cycle arrest (Figure 2G). The cell-cycle distribution (G1 phase, $S$ phase, and G2 phase) of bEnd.3 cells in the APEC $\mathrm{XM} \Delta c l b G$ group were similar to the control group (Figure $2 \mathrm{H}$ ).

The results for the $\gamma \mathrm{H} 2 \mathrm{AX}$ expression, megalocytosis level, and cell cycle phases in bEnd. 3 cells confirmed that the deletion of $c l b G$ reduced the colibactin production of APEC XM. It also supported the fact that APEC XM $\Delta c l b G / p c l b G$ restored the genotoxicity of colibactin. 


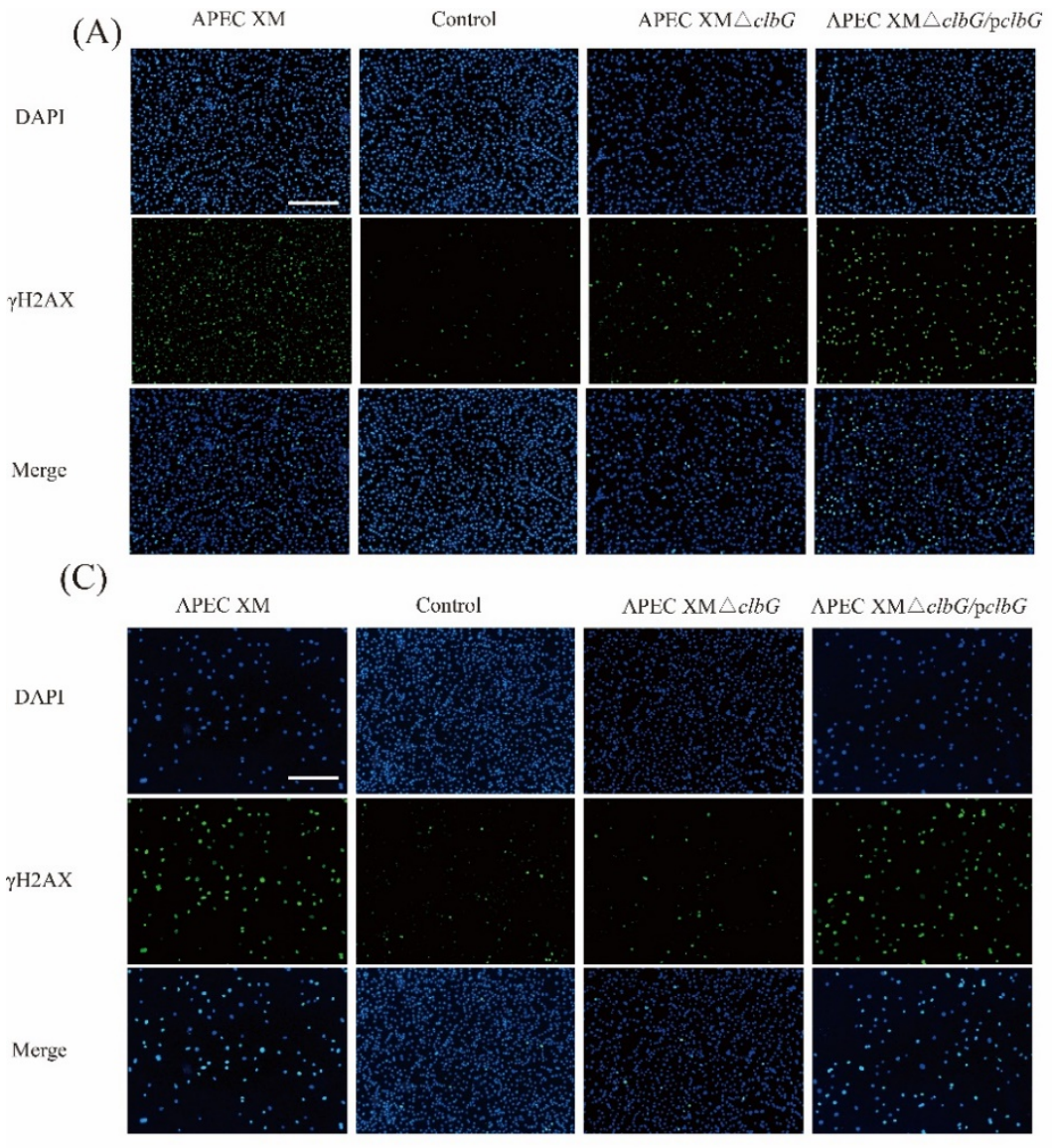

(B)

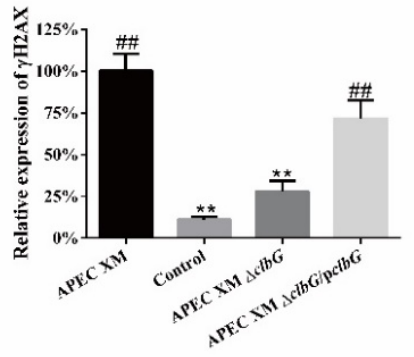

(D)

(E)
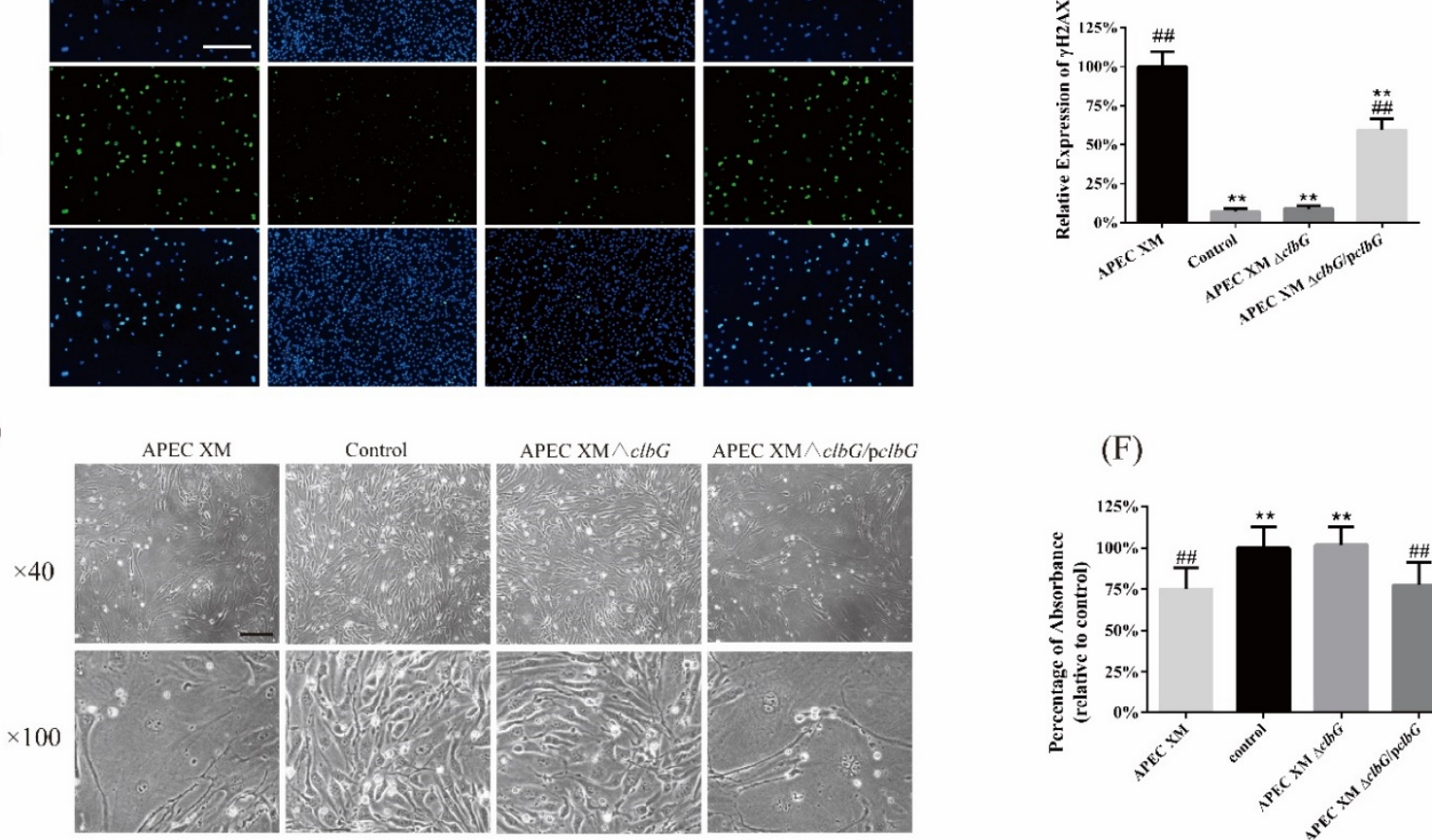

(G)
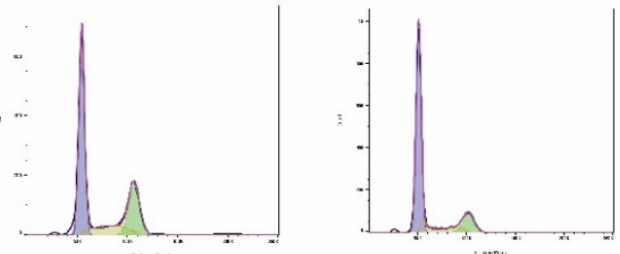

(H)

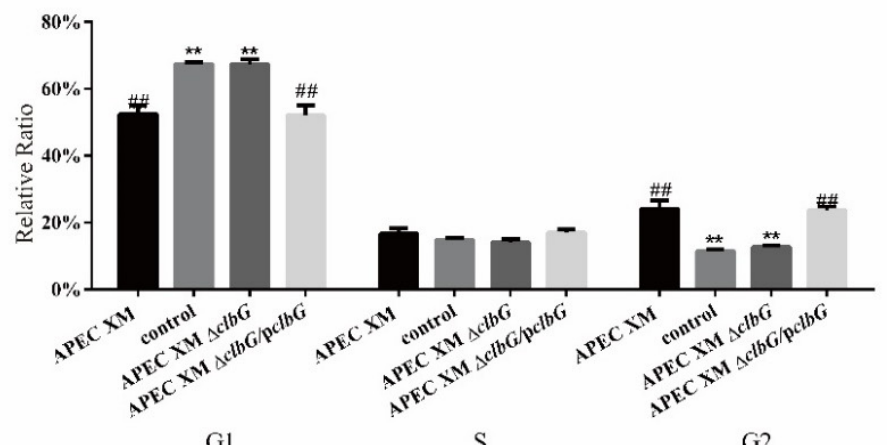

APEC XM $\Delta c l b G / \mathrm{p} c l b G$

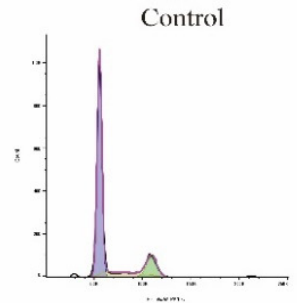

APEC XM $\triangle c l b G$

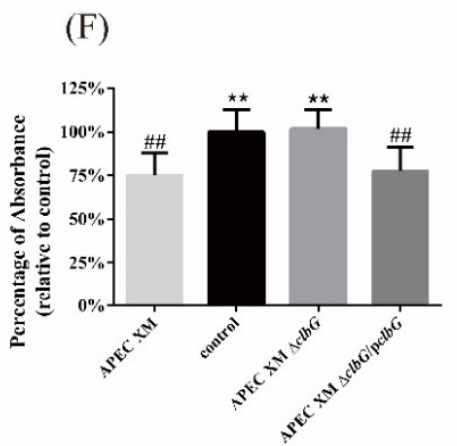

Figure 2. $\mathrm{ClbG}$ is required for colibactin synthesis and genotoxic effects of APEC XM on bEnd.3 cells. BEnd. 3 cells were infected with a multiplicity of infection (MOI) of 100 bacteria/cell for $4 \mathrm{~h}$ in the APEC XM, APEC XM $\triangle c l b G$ or APEC XM 
$\Delta c l b G / p c l b G$ group. For the control group, cells were not infected with any bacteria for $4 \mathrm{~h}$. After $4 \mathrm{~h}$ treatment, the bEnd.3 cell DNA double-strand breaks induced by colibactin were assayed by immunofluorescence staining of $\gamma \mathrm{H} 2 \mathrm{AX}$ at $0 \mathrm{~h}$ post-incubation (hpi) (A). The nuclear DNA and $\gamma \mathrm{H} 2 \mathrm{AX}$ are colored in blue and green, respectively (bar $=200 \mu \mathrm{m})$. The percentage of $\gamma \mathrm{H} 2 \mathrm{AX}$ positive cells within the total population of cells at $0 \mathrm{hpi}(\mathbf{B})$ are shown in bar graphs. The ratio of the APEC XM group was set as $100 \%$. After the same treatment, the bEnd.3 cell DSBs induced by colibactin were assayed by immunofluorescence staining $\gamma \mathrm{H} 2 \mathrm{AX}(\mathbf{C})$ and quantified (D) of $\gamma \mathrm{H} 2 \mathrm{AX}$ positive cells at $72 \mathrm{hpi}$. (E) Megalocytosis induced by colibactin was observed at $72 \mathrm{hpi}$ by an inverted microscope (bar $=100 \mu \mathrm{m})$. APEC XM and APEC XM $\Delta c l b G / \mathrm{p} c l b G$ induced a progressive enlargement of the bEnd.3 cell body and the nucleus. (F) The megalocytosis of methylene blue stained cells was quantified by the absorbance values at $630 \mathrm{~nm}$ by a microplate reader. The data of the control group was set as 100\%. (G) The cell cycles of bEnd.3 cells were assayed by flow cytometry (purple, G0/G1 phase; yellow, S phase; green, G2/M phase). APEC XM and APEC XM $\Delta c l b G / p c l b G$ resulted in G2/M phase accumulation in infected cells (H) Quantification analyses of cell-cycle distribution (G1 phase, S phase, and G2 phase) of bEnd.3 cells. The data were analyzed with one-way analysis of variance (ANOVA) and presented as the mean \pm standard errors of the mean for three independent experiments. ${ }^{* *}, p<0.01$, versus APEC XM group; \#\#, $p<0.01$, versus control group).

\subsection{ClbG Is Required for the Pathogenicity of APEC XM In Vivo}

The effect of the $c l b G$ gene on pathogenicity was evaluated using Institute of Cancer Research (ICR) mice by intraperitoneal injection of APEC XM, APEC XM $\Delta c l b G$, and APEC XM $\triangle c l b G / p c l b G$, respectively. The health status of the mice was assessed by a clinical score as described previously [33,34]. When mice of the APEC XM group were no longer able to walk (clinical score 3), mice of four groups were sacrificed and none of the mice died spontaneously. The mice showed depression, rough fur, eyelid closure with thick red-eye discharge, diarrhea, and neurological symptoms after the challenge with APEC XM (Figure 3A, clinical score 3). The mice in APEC XM $\Delta c l b G /$ pclbG group presented a sign of eyelid closure with thick eye discharge and diarrhea (Figure 3A, clinical score 2-3). In the APEC XM $\Delta c l b G$ group or the control group, there were very mild or no symptoms (Figure $3 \mathrm{~A}$, clinical score 0 ). The diff-quik dye of the cerebrospinal fluid (CSF, Figure 3B) demonstrated all mice in the APEC XM group and most mice (8/10) in APEC XM $\triangle c l b G / p c l b G$ group suffered meningitis (Figure 3C). None of the mice suffered meningitis in the APEC XM $\Delta c l b G$ or the control group. The absolute counts of white blood cells (Figure 3D), lymphocytes (Figure 3E), and neutrophils (Figure 3F) in the APEC XM group and APEC XM $\triangle c l b G / p c l b G$ group were lower than those in the control group. There were no significant differences between the APEC XM $\triangle c l b G$ and control group.

The bacterial loads in the blood (Figure 3G) and lung (Figure 3H) decreased significantly in the APEC XM $\triangle c l b G$, compared with the APEC XM group. The bacterial loads of the lung and blood in the APEC XM $\Delta c l b G / p c l b G$ group were similar to those in the APEC $\mathrm{XM}$ group. Importantly, no bacterium was isolated from brain tissue samples in the APEC $\mathrm{XM} \Delta \mathrm{clb}$ Group or the control group (Figure 3I).

The results of ICR mouse infection indicated that $c l b G$ is necessary for pathogenicity of APEC XM in vivo. 
(A)
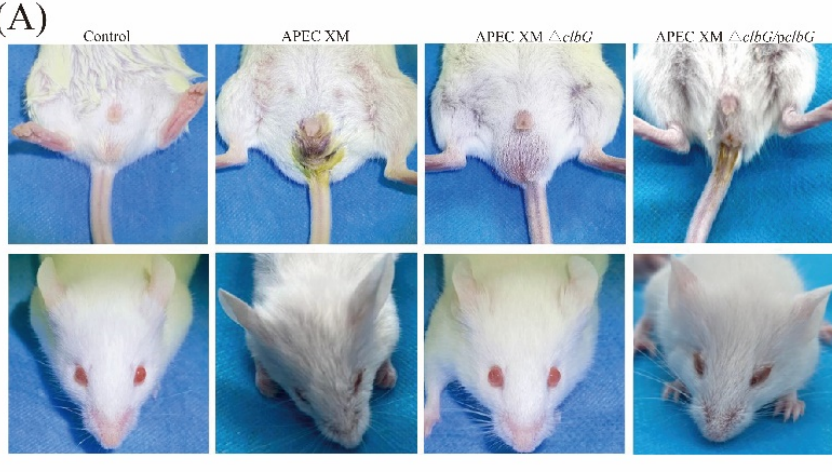

(B)
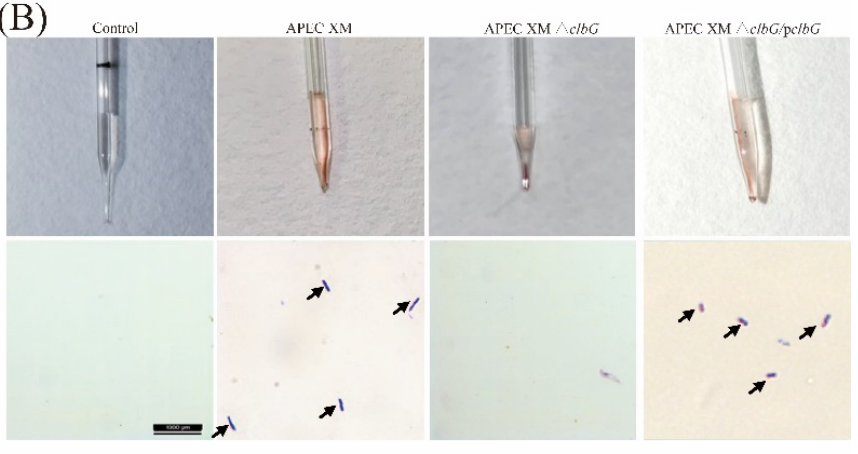

(C)

\begin{tabular}{lcccc}
\hline Dose of change & \multicolumn{3}{c}{ Positive of CSF } \\
\hline $1 \times 10^{7} \mathrm{CFU}$ & Control & APEC XM & APEC XM $\triangle c l b G$ & APEC XM $\Delta c l b G / \mathrm{p} c l b G$ \\
& $0 / 10$ & $10 / 10$ & $0 / 10$ & $8 / 10$ \\
\hline
\end{tabular}

(D)

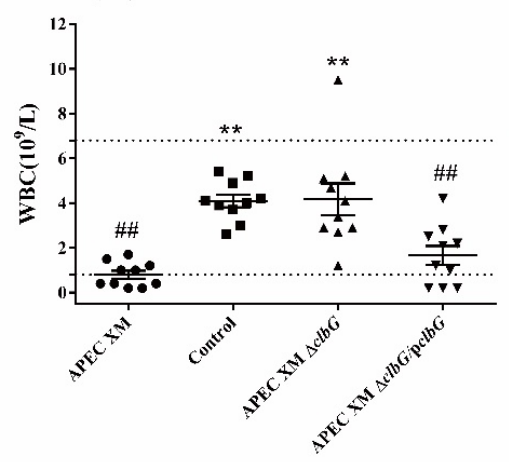

(G)

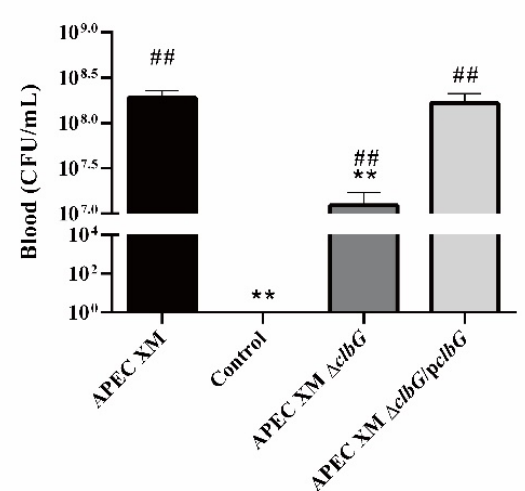

(E)

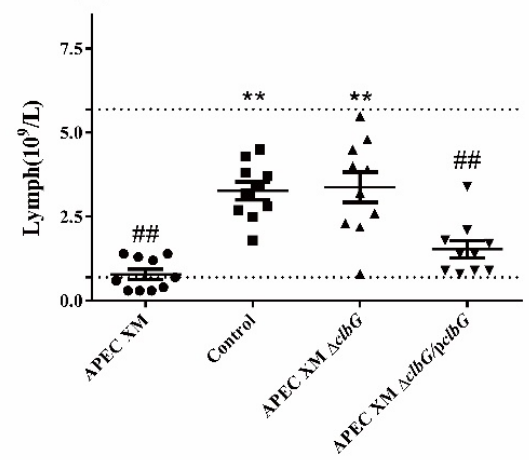

$(\mathrm{H})$

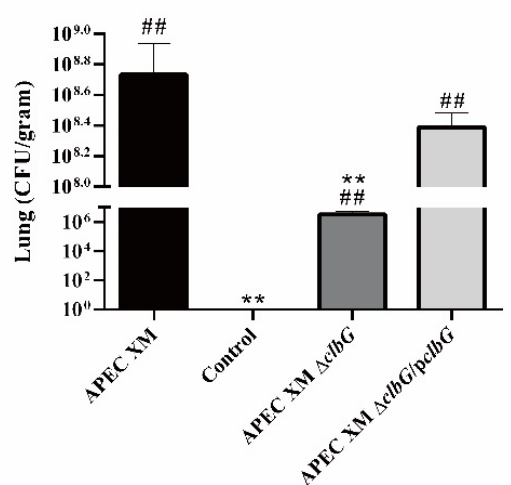

(F)

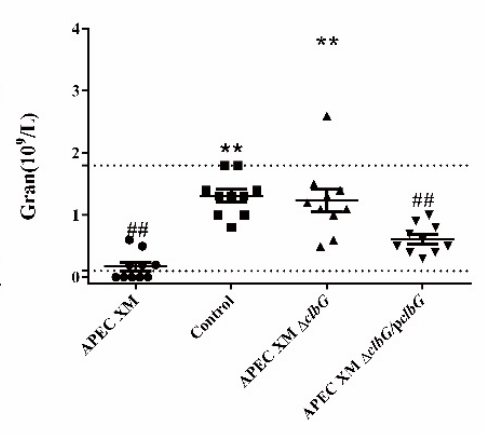

(I)

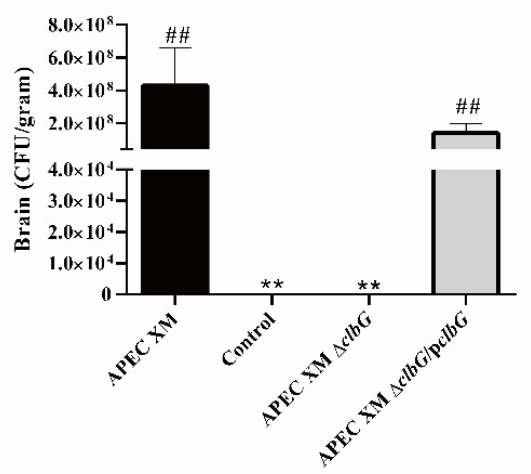

Figure 3. ClbG affects pathogenicity of APEC XM on 4-week Institute of Cancer Research (ICR) mouse. Four-week-old ICR mice were inoculated intraperitoneally with a dose of $10^{7}$ CFU. E. coli in $100 \mu \mathrm{L}$ saline or an equal volume of sterile saline. (A) The representative images of mice in each group. The mice in APEC XM group and the APEC XM $\triangle c l b G / p c l b G$ group displayed lackluster coat, eyelid closure with thick red ocular discharge (lower lane), and diarrhea (upper lane). (B) The physical examination (upper lane) and Diff-Quik staining (lower lane) of cerebrospinal fluid (CSF) samples. E. coli (Black arrow) were found in the CSF samples of the APEC XM group and the APEC XM $\Delta c l b G / \mathrm{p} c l b G$ group $(\mathrm{bar}=10 \mu \mathrm{m})$. (C) The presence of E. coli in CSF staining is the positive standard of meningitis. All mice in the APEC XM group and $80 \%$ mice in the APEC XM $\triangle c l b G / p c l b G$ group suffered meningitis, whereas no mice suffered meningitis in the APEC XM $\Delta c l b G$ or the control group. (D-F) Complete blood counts (CBC) test. The CBC data for white blood cells (D), lymphocytes (E), and neutrophils (F) are shown in the scatter plot. The dotted lines of the scatter plot charts represent the normal ranges of the cell population. The absolute counts of white blood cells, lymphocytes, and neutrophils declined in the APEC XM group 
and the APEC XM $\triangle c l b G$ /pclbG group. (G-I) Bacterial load assay for lung, blood, and brain. Calculation of bacteria from blood $(\mathbf{G})$, lung $(\mathbf{H})$, and brain $(\mathbf{I})$ in each group by plate counting. No bacterium was isolated from brain tissue samples in the control group nor the APEC XM $\Delta c l b G$ group. The results were analyzed with one-way ANOVA and presented as the mean \pm standard errors of the mean for three independent experiments. $\left({ }^{* *}, p<0.01\right.$, versus APEC XM group; \#\#, $p<0.01$, versus control group).

\subsection{Relative Cytokines Profiles and Histopathological Findings in Mouse Brains}

The relative expression levels of $I L-1 \beta, I L-6$, and TNF- $\alpha$ mRNA in brain tissues were measured by qRT-PCR. The relative expression of $I L-1 \beta$ (Figure $4 \mathrm{~A}$ ), $I L-6$ (Figure $4 \mathrm{~B}$ ), and TNF- $\alpha$ (Figure 4C) mRNA were similar between the APEC XM group and the APEC XM $\Delta c l b G / p c l b G$ group, and both of them were significantly increased compared with the control group. No significant differences were found between APEC XM $\triangle c l b G$ and the control group in the relative expression of these cytokines.

(A)

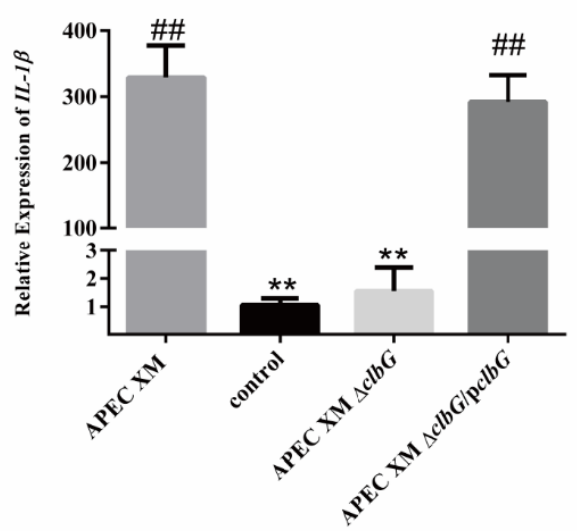

(D)

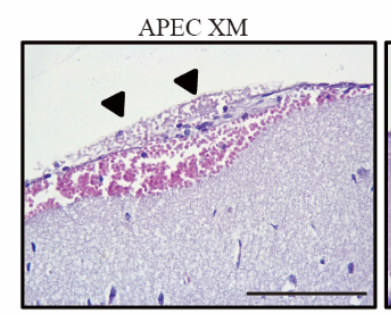

Pia Mater

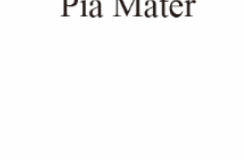

Cerebral Cortex

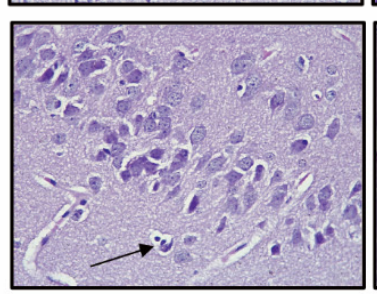

Medulla

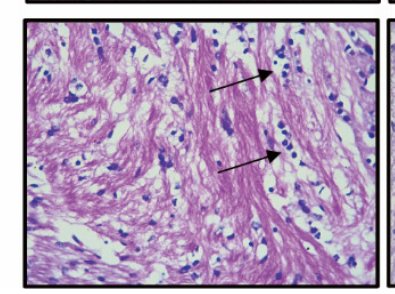

(B)

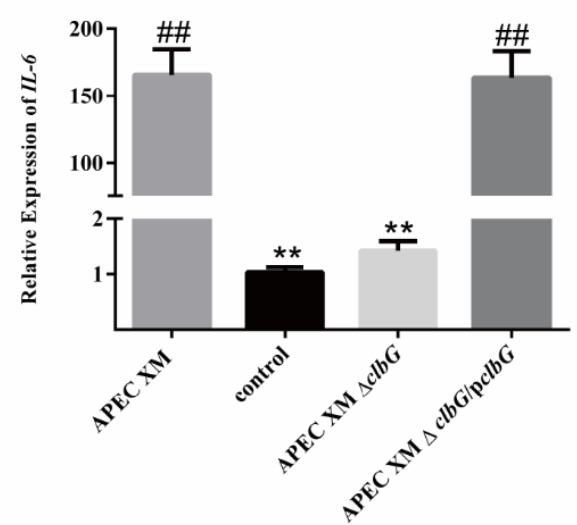

(C)

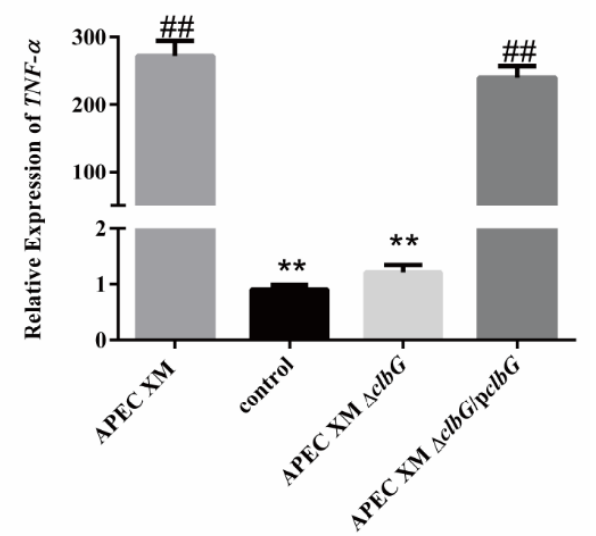

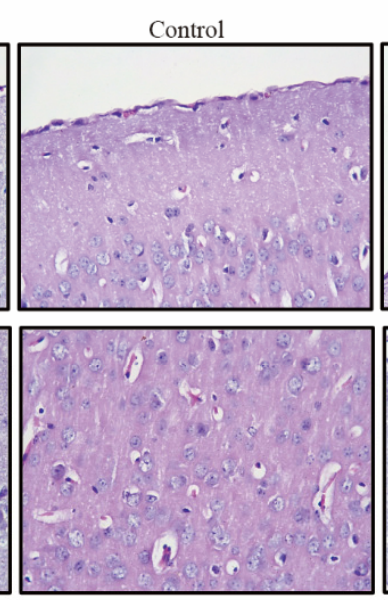

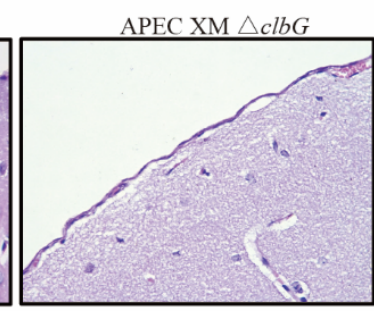

$\mathrm{APEC} \mathrm{XM} \triangle \mathrm{clbG} / \mathrm{p} c l b G$
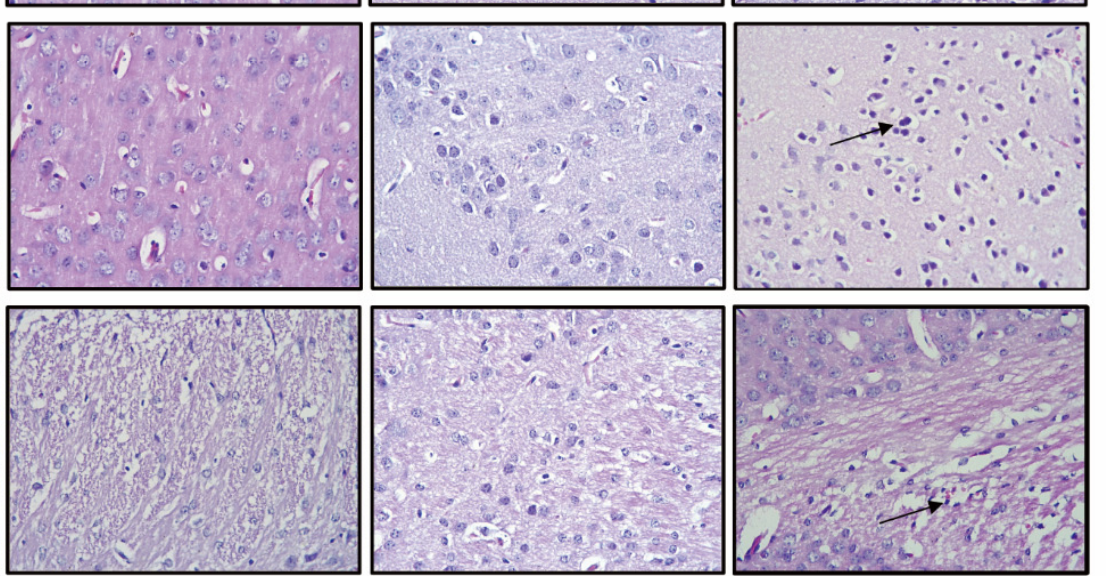

Figure 4. $\mathrm{ClbG}$ contributes to inflammation responses and brain damage in mice meningitis. Four-week-old ICR mice were inoculated intraperitoneally with a dose of $10^{7} \mathrm{CFU}$. E. coli in $100 \mu \mathrm{L}$ of saline or an equal volume of sterile saline for $12 \mathrm{~h}$. (A-C) The mRNA transcripts levels of $I L-1 \beta(\mathbf{A}), I L-6(\mathbf{B})$, and TNF- $\alpha$ (C) were determined by qRT-PCR from mouse brains 
of each group (normalized to GAPDH). The results were analyzed with one-way ANOVA and presented as the mean \pm standard errors of the mean for three independent experiments. $\left({ }^{*}, p<0.01\right.$, versus APEC XM group; \#\#, $p<0.01$, versus control group) (D) Histopathological analysis of brain tissue. Representative hematoxylin-eosin staining images of pia mater (upper lane), cerebral cortex (middle lane), and medulla (lower lane) of brain sections (bar $=100 \mu \mathrm{m})$. Leukocyte infiltration (Black Arrow) was observed in the pia mater, cerebral cortex, and medulla. The thickened pia mater with hemorrhage (Black Arrowhead) was observed in the brain section of the APEC XM group and the APEC XM $\triangle c l b G / p c l b G$.

The histopathological analysis showed a marked thickening and hemorrhage of the pia mater (Figure $4 \mathrm{D}$, black arrowhead), and moderate leukocyte infiltration in the pia mater, cerebral cortex, and medulla in the APEC XM group (Figure 4D, black arrow). Also, a slight hemorrhage in the medulla and a marked thickening and hemorrhage of the pia mater (Figure 4D, black arrowhead) were found in the APEC XM $\triangle \mathrm{clbG} / \mathrm{p} \mathrm{clbG}$ group. The histological changes mentioned above were not found in the APEC XM $\triangle c l b G$ or the control group.

The results of relative cytokines profiles and histopathological findings indicated that $c l b G$ is necessary for the pathogenicity of APEC XM in vivo.

\subsection{ClbG Contributes to the Disruption of the Blood-Brain Barrier In Vitro and In Vivo}

Western blotting was used to measure the expression of ZO- 1 and claudin- 5 protein in vitro. The levels of claudin-5 (Figure $5 \mathrm{~A}, \mathrm{~B}$ ) and ZO-1(Figure $5 \mathrm{~A}, \mathrm{C}$ ) decreased significantly in the APEC XM group and the APEC XM $\triangle c l b G / p c l b G$ group, compared to the control group. The expression of claudin- 5 and ZO- 1 in the APEC XM $\triangle c l b G$ group was higher than those in the APEC XM group.

Evans blue dye analysis was performed to measure the integrity and permeability of the blood-brain barrier (BBB) in vivo. The brain from APEC XM infected mouse was stained blue by Evans blue dye (Figure 5D). The extravasation of Evans blue dye from the brain in the APEC XM $\triangle c l b G$ and the control group were significantly lower than those in the APEC XM group and the APEC XM $\Delta c l b G / p c l b G$ group (Figure 5E).

Then, Western blotting and immunohistochemical staining were used to measure the tight junctional protein expression in vivo. The expression of ZO-1 (Figure 5F,G), claudin-5 (Figure 5F,H), and occludin (Figure 5F,I) decreased significantly in the APEC XM group and the APEC XM $\triangle c l b G / p c l b G$ group, compared with the control group. There were no significant differences in the expression of ZO-1, claudin-5, and occludin between the APEC XM $\triangle c l b G$ group and the control group.

The immunohistochemical staining showed the expression of ZO-1 (Figure 5J), claudin-5 (Figure $5 \mathrm{~N}$ ), and occludin (Figure 5R) in brain sections per group. The relative optical density of ZO-1 in pia mater (Figure 5K), cerebral (Figure 5L), and hippocampus (Figure 5M) from the APEC XM group and the APEC XM $\triangle c l b G / p c l b G$ group decreased significantly, compared to the control group. The relative optical densities of claudin- 5 and occludin in the APEC XM group and the APEC XM $\Delta c l b G / p c l b G$ group showed similar expression patterns. All the detected tight junctional proteins in pia mater, cerebral, and hippocampus of brain sections from the APEC XM $\triangle c l b G$ group were similar to those from the control group.

Based on the results above, the deletion of $c l b G$ contributes to the disruption of the BBB by APEC XM in vitro and in vivo. 


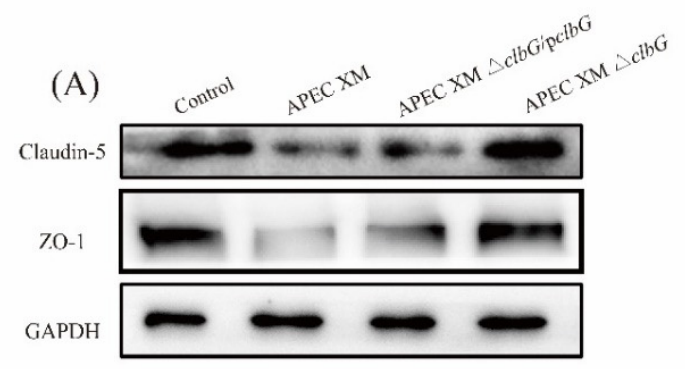

(D)

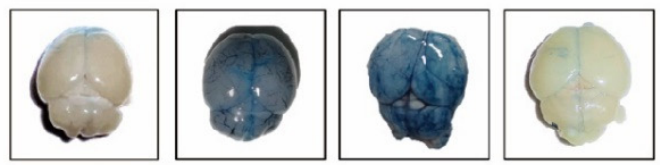

control.

AIPC XM

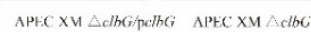
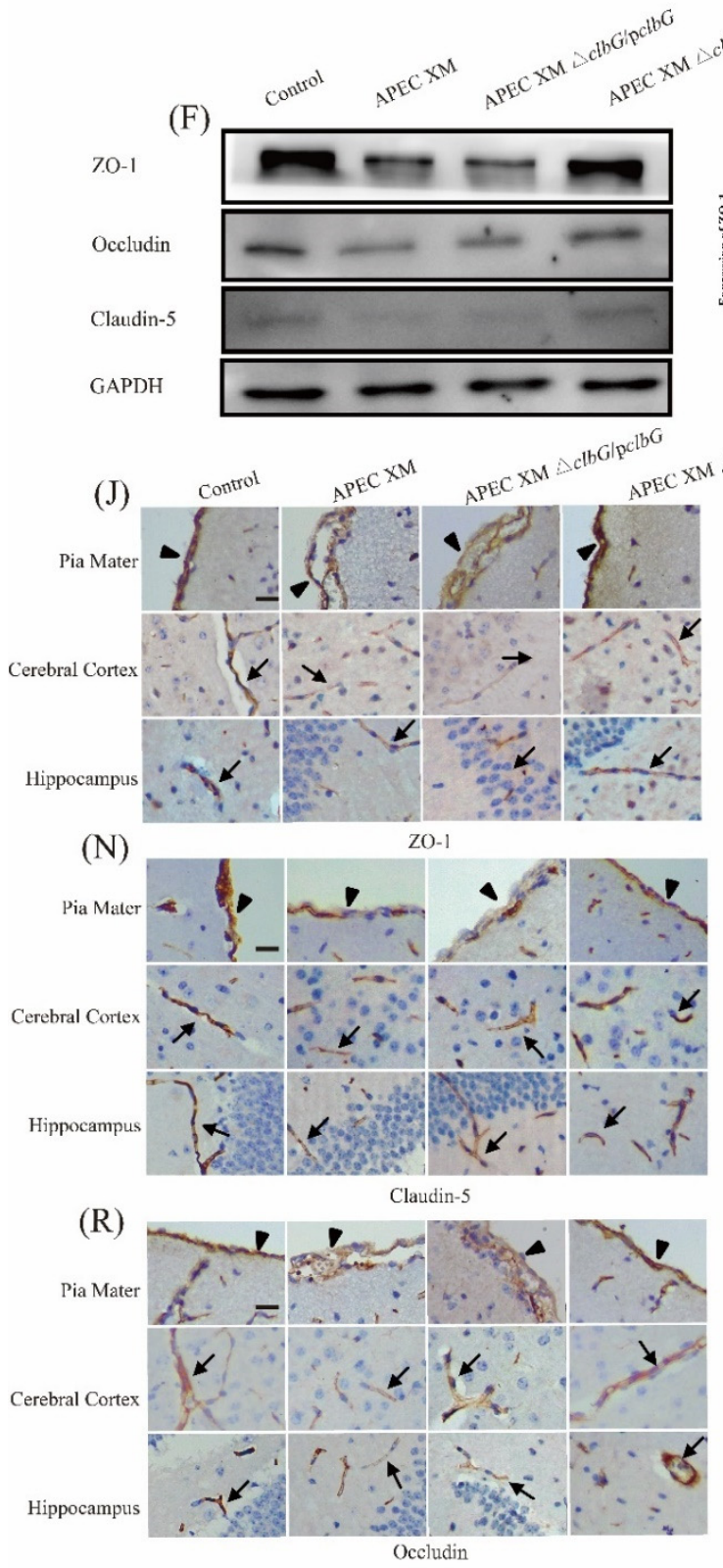

(G)

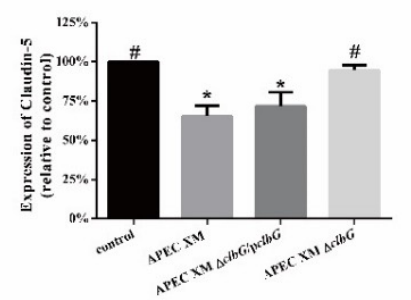

(E)
(C)

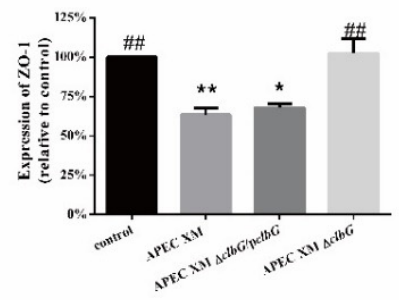

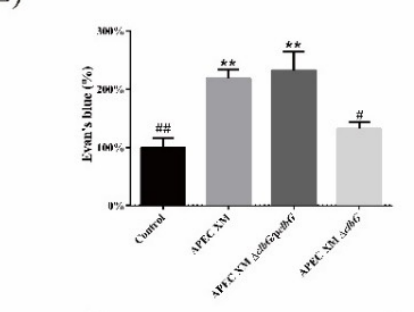

(H)

(I)

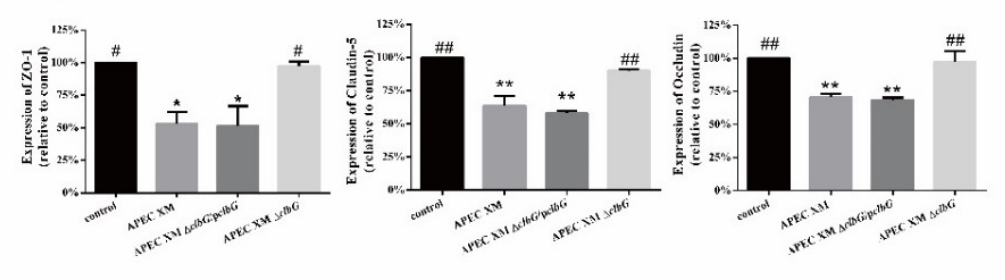

(L)

(M)

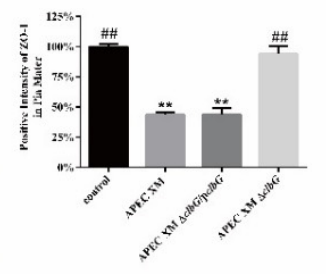

(O)

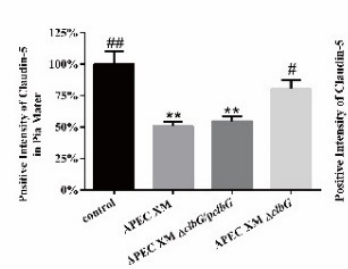

(S)

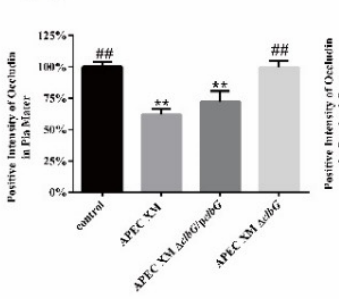

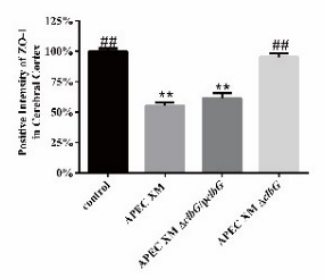

(P)

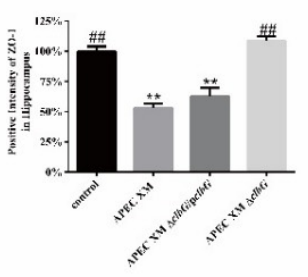

(Q)

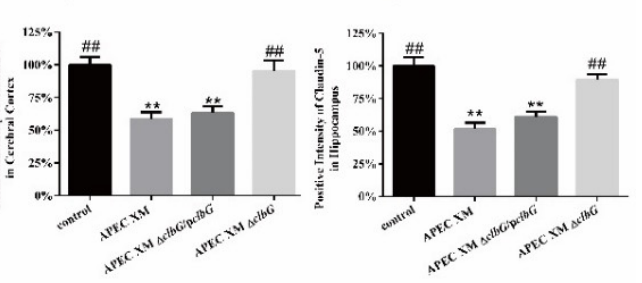

(T)

(U)

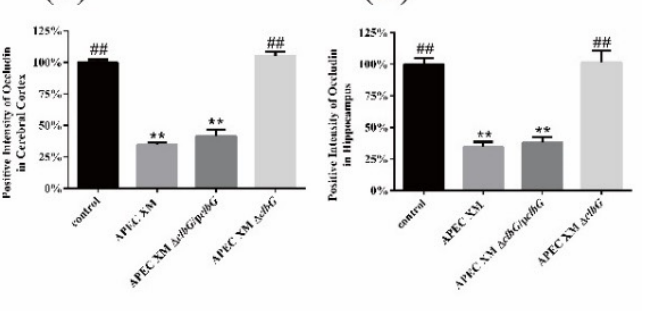

Figure 5. $\mathrm{ClbG}$ contributes to the disruption of the blood-brain barrier. (A-C) The expression of claudin-5 and ZO- 1 in vitro. BEnd. 3 cells were infected with a multiplicity of infection (MOI) of 100 bacteria/cell for $4 \mathrm{~h}$ in the APEC XM, APEC XM 
$\Delta c l b G$ and APEC XM $\Delta c l b G / p c l b G$ group in the following experiments. Cells without infection of bacteria were set as the control group. Blots (A) and relative protein levels of claudin-5 (B) of and ZO-1 (C), normalized to GAPDH. The data of the control group was set as 100\%. ZO-1 and claudin-5 proteins decreased significantly in the APEC XM group and APEC XM $\Delta c l b G /$ pclbG group, compared to the control group. (D-U) Four-week-old ICR mice were inoculated intraperitoneally with a dose of $10^{7}$ CFU E. coli in $100 \mu \mathrm{L}$ saline or an equal volume of sterile saline for $12 \mathrm{~h}$. (D) The representative bright-field photographs of Evans blue stained mouse brains were taken in dorsal view. (E) The amount of Evans blue dye was quantified by measuring the absorbance $\left(\mathrm{OD}_{630}\right)$ after brain homogenization and precipitation. The data of the control group were set as $100 \%$. Increase of blood-brain barrier permeability was found in the APEC XM group and APEC XM $\Delta c l b G / p c l b G$ group, but not in APEC XM $\Delta c l b G$ group. (F-I) The expression of claudin-5, occludin, and ZO-1 in vivo was measured by Western blotting. Representative Western blots (F) and the relative protein levels of and ZO-1 (G), claudin-5 $(\mathbf{H})$, and occludin (I), normalized to GAPDH. The data of the control group was set as 100\%. ZO-1, occludin, and claudin-5 proteins decreased significantly in the APEC XM group and the APEC XM $\Delta c l b G / p c l b G$ group, compared to the control group. (J-U) The expression of tight junction proteins in vivo was also measured by immunohistochemistry (IHC). The representative IHC pictures of ZO-1 (J), claudin-5 (N), and occludin (R) protein levels in the pia mater, cerebral cortex, and hippocampus of brain sections. The black arrowheads pointed to the pia maters and the black arrows pointed to the capillaries (bar $=20 \mu \mathrm{m}$ ). Graphical representations of the relative optical densities of ZO-1 (K-M), claudin-5 (O-Q), and occludin (S-U) in pia mater, cerebral, and hippocampus, respectively. The data of the control group was set as $100 \%$. The results were analyzed with one-way ANOVA and presented as the means \pm standard errors of the mean for three independent experiments. $(* *, p<0.01, *, 0.01<p<0.05$ versus APEC XM group; \#\#, $p<0.01, \#, 0.01<p<0.05$ versus control group).

\section{Discussion}

E. coli is the most common Gram-negative bacteria that causes newborn meningitis and leads to over $10 \%$ of mortality $[35,36]$ and approximately $50 \%$ of neurological disabilities [37] in newborn infections. E. coli has many important virulence factors [38] and bacterial genotoxins [39] to survive in the bloodstream and invade the meninges of newborns. Colibactin was first found in an NMEC strain (IHE3034) [1], and the mRNA levels of $p k s$ island genes changed in in vitro infection of APEC XM in our previous work [4]. Most studies of colibactin have focused on gut homeostasis or colorectal cancer, but limited studies have been undertaken regarding meningitis. In this study, we established a 4-week ICR mouse meningitis model to find out the contribution of $c l b G$ in the development of meningitis. The results indicated that $c l b G$ was a necessary component for the synthesis of genotoxic colibactin and impact the development of meningitis in mouse.

Freestanding acyltransferase (AT, $\mathrm{ClbG}$ ) is an important member of the PKS unit in pks island [1]. AM-ACP incorporation is critical for constructing genotoxic metabolites of colibactin [1]. The ${ }^{14} \mathrm{C}$ gel autoradiography assay confirmed that $\mathrm{ClbG}$ was the only component in the $p k s$ assembly line to recognize the AM-ACP extender unit and transfer AM-ClbE to multiple PKS modules, including PKSs that lack functional AT domains (ClbC, $\mathrm{ClbK}$, and $\mathrm{ClbO}$ ) and a cis-AT PKS (ClbI) [32]. Therefore, $\mathrm{ClbG}$ is necessary for genotoxin production [40]. In line with previous studies of genes in the $p k s$ island (such as $c l b A$ [30] or $c l b P$ [26]), deletion of $c l b G$ repressed colibactin production and reduced genotoxicity to the bEnd. 3 cells in vivo, which indicated that $c l b G$ was a key gene for producing colibactin in APEC XM strain. The results of colibactin cytotoxicity assays also showed that APEC $\mathrm{XM} \Delta c l b G / \mathrm{p} c l b G$ restored the genotoxicity. In addition, the deletion of $c l b G$ affected the pathogenicity of newborn ICR mice in vivo as observed in this study. After the invasion of the host, pathogens need to rapidly adjust to the microenvironments of different tissues and colonize in organs to cause bacteremia and systemic infections [30]. A high degree of bacteremia is a prerequisite for E. coli to result in meningitis [41,42]. Unlike the high degree of organ colonization in the APEC XM group, the bacterial loads in the APEC XM $\triangle c l b G$ group decreased in the lungs and blood. Colibactin may not only act as a classical virulence factor facilitating bacterial translocation and survival [43], but also as a fitness factor, improving the colonization of the gastrointestinal tract by slowing the renewal of enterocytes [23]. Colibactin induced a decrease of regulatory T cell $\left(\mathrm{CD} 4{ }^{+} \mathrm{CD} 25^{+} \mathrm{FoxP}^{+}\right)$ populations [44] in the newborn rat early colonized by $p k^{+}{ }^{+}$. coli. Meanwhile, APEC XM 
induced a decrease of lymphocytes in meningitic mice, which was alleviated in APEC XM $\triangle c l b G$ infected mice. The decrease in lymphocytes was similar to previous experimental $\mathrm{pks}^{+}$septicemic mice, and the survival rate of mice or rats in sepsis and meningitis induced by $\mathrm{pss}^{+}$E. coli decreased $[26,29]$. After the invasion of the blood compartment, the bacteria entered the central nervous system, and colonization of the brain is another key step to meningitis development [37]. In histopathological analysis, brain injuries including necrotic cortical injury and apoptotic hippocampal injury $[45,46]$ were found in the E. coli meningitis mice. All these histopathological signs, such as the severe thickening of the pia mater, leukocyte infiltration into brain tissue and hemorrhage shown in the APEC XM group, were not found in the APEC XM $\Delta c l b G$ group. The results mentioned above indicate that $c l b G$ is a necessary part of the synthesis of genotoxic colibactin, which is also strongly related to meningitis induced by APEC XM. To date, it is the first study to demonstrate the direct pathogenicity of $c l b G$ in vivo.

In the pathogenesis of cerebral injury in bacterial meningitis, TNF- $\alpha$, IL- 6 , and IL-1 $\beta$ are major early response cytokines that trigger, often in synergy, a cascade of inflammatory mediators, including other cytokines, oxygen intermediates, and chemokines [47]. These cytokines are produced by multiple brain cell types, such as cerebromicrovascular endothelial cells [48], astrocytes [49], and microglia [50]. The mRNA expression of TNF- $\alpha, I L-6$, and $I L-1 \beta$ was markedly up-regulated in the pneumococcal [51,52] or E. coli meningitis [53-55] rodent model, similar to the relative expression of detected cytokines in the APEC XM group. The overproduction of cytokines in the brain could trigger immune system hyperactivity and induce a "cytokine storm" damaging the central nervous system. IL- $1 \beta$ contributes to macrophage recruitment, Streptococcus pneumoniae clearance [56], and the protection of mice from lethal Gram-negative bacterial infection [57]. IL-1 $\beta$ also induces the expression of many other cytokines [58] and growth factors [59], such as TNF- $\alpha$ and IL-6. TNF- $\alpha$ is another important early-response cytokine and is related to a fatal outcome in meningitis [60]. However, TNF- $\alpha$ deficiency did not affect the brain bacterial titers and leukocyte recruitment into the subarachnoid space in the mouse model of central nervous system infection in one study [61]. Both IL-1 $\beta$ and TNF- $\alpha$ are bone marrow stimulants that grow in a number of myeloid progenitors and promote the recruiting of neutrophils in the inflammation site [60]. IL-6 is a pleiotropic cytokine with both pro-inflammatory and anti-inflammatory effects. It appears to be a good marker of severity during bacterial infection [62]. IL-6 deficiency caused an increased leukocyte concentration in CSF of pneumococcus-infected mice. IL-6 appears to control the inflammatory response by down-regulating the response of chemokines and/or proinflammatory cytokines [47]. In addition, these inflammatory cytokines play a role in BBB integrity. IL-17, IL-6, and/or TNF- $\alpha$, alone or in combination, trigger an inflammatory reaction, which leads to a significant increase of permeability and a decrease of tight junction proteins (ZO-1 and claudin-5) in bEnd.3 BBB model [63]. Interestingly, TNF- $\alpha$ was shown to exert different effects on tight junction proteins disruption in different organs. For example, TNF- $\alpha$ reduced occludin and ZO-1 expressions in pulmonary microvascular endothelial cells [64] and hCMEC/D3 cells [65]. One study reported that the response of TNF- $\alpha$ and IL- $\beta$ induced leak in human

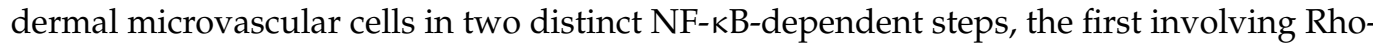
associated kinase and the second likely to involve an as yet unidentified but structurally related protein kinase(s) [66]. In a co-culture model, consisting of human brain microvascular endothelial cells and pericytes, changes in claudin-5 localization and expression after TNF- $\alpha$ treatment and recovery time were dependent on TNF- $\alpha$ concentration [67]. In the meantime, IL-6 increased endothelial permeability and produced ZO-1 mislocalization, actin structure remodeling, and increased actin contractility [68]. APEC XM $\triangle c l b G$ did not increase the relative mRNA expressions of $T N F-\alpha, I L-6$, and $I L-1 \beta$ in diseased mice, which might be a reason for the relative integrity of the BBB in this group. However, more studies are needed to elucidate the mechanism of tight junction proteins degradation by $c l b G$.

$\mathrm{BBB}$ regulates the transport of various molecules and maintains brain homeostasis. The disruption of BBB is a hallmark event in the pathophysiology of bacterial meningi- 
tis [69]. Structurally, the inter-endothelial tight junction complexes comprising occludin, claudins, and membrane-directed scaffolding proteins (such as zonula occludentes-1, ZO-1) contribute to the physical barrier nature of BBB and strictly limit the molecular/cellular influx from circulation $[70,71]$. ZO-1, claudin-5, and occludin decreased at the transcript and/ or protein level of brain endothelial cells after Group B Streptococcus [72-74], Neisseria meningitidis [75], Streptococcus suis [76], or E. coli [77] infection. In vitro, the disruption of tight junction proteins in bEnd. 3 cells were alleviated in the APEC XM $\Delta c l b G$ group, as well as an in vivo mouse model by immunohistochemistry and Western blotting assays. The vascular leakage was also reduced in the APEC XM $\triangle c l b G$ group. Therefore, $c l b G$ might play an important role in disordering the tight junction proteins of BBB. ZO-1 was first identified as a tight junction-associated protein and expressed on both EC and epithelial cell surfaces [78]. It serves as a scaffold for tight junction formation by binding to the C-terminal of the cytoplasmic tail of occludin and the cytoskeletal protein spectrin. When $\mathrm{ZO}-1$ expression is reduced or dissociated from membrane proteins, the BBB stringency is compromised. Occludin, a $65-\mathrm{kD}$ protein, was the first tight junction-associated transmembrane protein identified and was related to cytoskeletal signaling proteins (ZO-1 and ZO-2) [79]. The barrier function of occludin depends on its special structure domains. To date, multiple factors, such as matrix metalloproteinases (MMPs)-dependent degradation [80], phosphorylation [81], ubiquitination [82], and other cytokines [83] (IL-1 $\beta$, TNF- $\alpha$, and IFN- $\gamma$ ), have been proven to regulate occludin functions on BBB permeability. Claudin- 5 is present in both human and mouse early fetus brain vessels and continues to increase during postnatal development for BBB maturation [84,85]. Claudin-5 is observed as a key component of the tight junction strand for selectively decreasing the permeability to ions, particularly in brain endothelial cells. Significantly, the conserved cysteines of claudin-5 were crucial for maintaining high transepithelial electrical resistance [86]. The dysfunction of claudin- 5 protein was related to endothelial permeability in a series of pathological processes, including inflammation, tumor edema [87], toxic damage [88], and high glucose damage [89].

\section{Conclusions}

In summary, our results showed that $c l b G$ is a key virulence factor for APEC XM to induce meningitis. $c l b G$ contributed to the disruption of tight junction proteins expression, and the increase in the inflammatory response in vivo and in vitro infection. The experimental result indicated that the blockage of the colibactin production, through the deletion of $c l b G$, substantially hindered APEC XM survival in the bloodstream. The results of the mouse pathogenicity test suggested that APEC XM may take advantage of blood to gain access to the central nervous system, which might require the involvement of colibactin.

\section{Materials and Methods}

\subsection{Ethics Statement}

The animal experiments followed the National Institute of Health guidelines for the ethical use of animals in China. All procedures were approved by the Animal Care and Ethics Committee of Yangzhou University. Four-week-old ICR mice were provided by the Comparative Medicine Center of Yangzhou University (License number: SCXK (Su) 2017-0007). All mice had free access to food and water under a $12 \mathrm{~h} \mathrm{light/dark} \mathrm{cycle}$ and were monitored twice a day. The tissue samples were collected in mice under isoflurane anesthesia. The mice were finally euthanized via isoflurane anesthesia to minimize the suffering.

\subsection{Bacterial Strains, Growth Conditions, and Plasmids}

The APEC XM strain (O2: K1, donated by Dr. Guoqiang Zhu, Yangzhou University) was isolated from the brain of a duck with meningitis and septicemia. APEC XM strain grew on Luria-Bertani (LB) plates or in LB broth $(180 \mathrm{rpm} / \mathrm{min})$ at $37^{\circ} \mathrm{C}$ aerobically. The culture medium and agar plates, with the addition of ampicillin $(100 \mu \mathrm{g} / \mathrm{mL})$ or 
chloramphenicol $(34 \mu \mathrm{g} / \mathrm{mL})$, as appropriate. The strains and plasmids used in this study were listed in Table 1.

Table 1. Summary of bacterial strains, plasmids, and primers used in this study.

\begin{tabular}{|c|c|c|}
\hline Strain or Plasmid & Characteristic or Function & Source \\
\hline $\begin{array}{c}\text { Strains } \\
\text { Avian pathogenic Escherichia coli } \\
\text { (APEC) XM } \\
\text { APEC XM } \Delta c l b G \\
\text { APEC XM } \Delta c l b G / \text { pclbG }\end{array}$ & $\begin{array}{l}\text { Virulent strain of APEC } \\
\text { Deletion mutant of } c l b G \text { with APEC XM background } \\
\text { APEC-XM } \Delta c l b G \text { with the vector pACYC184-clbG, } \mathrm{Cm}^{\mathrm{r}}\end{array}$ & $\begin{array}{c}\text { Donated by Dr. Guoqiang Zhu, } \\
\text { Yangzhou University } \\
\text { This study } \\
\text { This study }\end{array}$ \\
\hline $\begin{array}{l}\text { Plasmid } \\
\text { pKD46 } \\
\text { pKD3 } \\
\text { pCP20 } \\
\text { pACYC184-clbG }\end{array}$ & $\begin{array}{c}\lambda \text { red recombinase expression plasmid } \\
\text { pANTS } \gamma \text { derivative containing FRT-flanked, } \mathrm{Cm}^{\mathrm{r}} \\
\text { temperature-sensitive replication and thermal induction of FLP } \\
\text { synthesis } \\
\text { pACYC184 containing the promoter followed by the full-length } \\
\qquad l b G, \mathrm{Cm}^{\mathrm{r}}\end{array}$ & $\begin{array}{l}{[90]} \\
{[90]} \\
{[90]}\end{array}$ \\
\hline $\begin{array}{c}\text { P1 } \\
\text { P2 } \\
\text { P3 } \\
\text { P4 } \\
\text { P5 } \\
\text { P6 } \\
\text { GAPDH } \\
I L-1 \beta\end{array}$ & $\begin{array}{c}\text { Sequence }\left(5^{\prime} \rightarrow 3^{\prime}\right) \\
\text { GTCCTCTTCGCTGGATGT } \\
\text { GAACATCAGTGCGACATC } \\
\text { TGCGCACTGG } \\
\text { CAGCCACATCGGCGGCGCGGTGATGGCGTGTGGCTGTC } \\
\text { TGTGTAGGCTGGAGCTGCTTC } \\
\text { GCTCCGGTTCGCAATATGTAGGCATGGCAC } \\
\text { GGTGGCTGTATGAGCGTTCATATGAATATCCTCCTTAG } \\
\text { CTAACGCAGTCAGGCACCGTGTATGAC } \\
\text { GAAGGATGTCGCACTGATG } \\
\text { GTGCCGCCGGCTTCCATTTACGCC } \\
\text { TGTCCGCCGTTG } \\
\text { AACGGGAAGCCCATCACCATC } \\
\text { AAGACACCAGTAGACTCCACGA } \\
\text { ATGAAAGACGGCACACCCAC } \\
\text { GCTTGTGCTCTGCTTGTGAG } \\
\text { TGCAAGAGACTTCCATCCAGT } \\
\text { GTGAAGTAGGGAAGGCCG } \\
\text { ACTGAACTTCGGGGTGATCG } \\
\text { TGATCTGAGTGTGAGGGTCTGG }\end{array}$ & $\begin{array}{c}\text { Product size } \\
1150 / 275\end{array}$ \\
\hline
\end{tabular}

\subsection{Construction of clbG Deletion and Complemented Mutants}

Bacteriophage $\lambda$ Red recombinase system was used to inactivate the $c l b G$ of APEC XM strain with the primers $\mathrm{P} 3 / \mathrm{P} 4$ and plasmid pKD3, pKD46, and pCP20 as described previously [90] (Table 1). The full length of the $\mathrm{clbG}$ gene was cloned into plasmid pACYC184 and the recombinant plasmid pACYC184-clbG was transformed into $c l b G$-deletion mutant for constructing the complemented mutant. The deletion and complemented mutants were confirmed by the combination of PCR and DNA sequencing. All primers and plasmids used in this study are listed in Table 1.

\subsection{Growth Curves}

Generally, $200 \mu \mathrm{L}\left(1 \times 10^{8} \mathrm{CFU}\right)$ bacteria in the mid-log phase were inoculated in LB medium with or without ampicillin at $37^{\circ} \mathrm{C}$ with $180 \mathrm{rpm} / \mathrm{min}$ shaking. Then, $200 \mu \mathrm{L}$ samples were taken every $1 \mathrm{~h}$ and detected at $630 \mathrm{~nm}$ using a spectrophotometer (BioTek ELx800, Winooski, VT, USA) for the optical density, until the bacteria grew at a static phase. The above experiments were repeated three times independently. The growth curves were drawn by GraphPad Prism 5.0 software (GraphPad Software, San Diego, CA, USA).

\subsection{Cell Culture}

The bEnd. 3 cells (ATCC CRL-2299, American Type Culture Collection, Manassas, VA, USA) were cultured in the DMEM (Invitrogen, Carlsbad, CA, USA), supplemented with $10 \%$ heat-inactivated fetal bovine serum (FBS; Gibco, Carlsbad, CA, USA) in a humidified incubator at $37^{\circ} \mathrm{C}$ with $5 \% \mathrm{CO}_{2}$. 


\subsection{Colibactin Cytotoxicity Assays}

The bEnd. 3 cells (about 75\% confluence) were infected with APEC XM, APEC XM $\triangle c l b G$, and APEC XM $\Delta c l b G / p c l b G$ with a MOI of 100 , respectively. After $4 \mathrm{~h}$ infection, bEnd. 3 cells were washed three times with PBS, and further incubated in DMEM with $10 \%$ FBS containing gentamicin $(100 \mu \mathrm{g} / \mathrm{mL})$ until the next treatment.

Colibactin induces an increase in the $\gamma \mathrm{H} 2 \mathrm{AX}$ protein of infected cells due to DSBs. The immunofluorescence was used to find the $\gamma \mathrm{H} 2 \mathrm{AX}$ expression of infected cells at $0 \mathrm{hpi}$ and $72 \mathrm{hpi}[1,91]$. The cells were infected and fixed as described above. After that, the cells were permeabilized with $0.1 \%$ Triton X-100 for $20 \mathrm{~min}$ and processed for immunofluorescence following a standard protocol [92]. The primary antibody was a monoclonal rabbit anti phosphorylated H2AX (\#9718, Cell Signaling Technology). The secondary antibody was a goat-anti-rabbit IgG $(\mathrm{H}+\mathrm{L})$ Alexa Fluor Plus 488 (A-21070, ThermoFisher Scientific). The cells were stained with 4',6-diamidino-2-phenylindole (DAPI; Beyotime, Shanghai, China). Finally, the GFP fluorescence was detected and photographed by fluorescence microscope (Leica TCS SP8; Leica Corp., Wetzlar, Germany).

To visualize the colibactin-inducing megalocytosis, the cells were incubated for $72 \mathrm{hpi}$ containing gentamicin. Then, the cells were fixed with $4 \%$ paraformaldehyde and stained with $0.1 \%$ methylene blue for $20 \mathrm{~min}$. The cells were observed by an inverted microscope. The cytotoxic effects of each strain were quantified by the absorbance values at $630 \mathrm{~nm}$ by a microplate reader (BioTek ELx800, Winooski, VT, USA).

Under the same infection condition, the cell cycle of bEnd.3 cells was detected at 48 hpi by the flow cytometer [1,91]. The cells were collected and washed with PBS three times. Then, cells were resuspended in $70 \%$ ice-cold ethanol at $4{ }^{\circ} \mathrm{C}$ overnight for fixation. The cells were centrifuged at $800 \mathrm{~g}$ for $10 \mathrm{~min}$ at $4{ }^{\circ} \mathrm{C}$ and washed with PBS. FxCycle ${ }^{\mathrm{TM}}$ PI/RNase staining solution (F10797, Thermo Fisher Scientific, Waltham, MA, USA) was used to stain cells at room temperature for $15 \mathrm{~min}$ and analyzed for DNA content. Data were acquired on a BD LSRFortessa ${ }^{\mathrm{TM}}$ flow cytometer (BD Biosciences, Franklin Lakes, NJ, USA) with 10,000 events/determination and analyzed with Flowjo software (Tree Star Inc., Ashland, OR). The experiments were repeated three times independently.

\subsection{E. coli Meningitis Mouse Model}

The mouse E. coli meningitis model was established as previously described [93] (Figure 6). Forty 4-week-old ICR mice were randomly divided into four groups, and each group included 10 mice (five males and five females). The mice were inoculated intraperitoneally with a dose of $10^{7} \mathrm{CFU}$ E. coli in $100 \mu \mathrm{L}$ saline or an equal volume of sterile saline. The clinical symptoms of the mice were observed after $8 \mathrm{~h}$ poi. The health status of the mice was assessed by a clinical score ( 0 , no apparent behavioral abnormality; 1, moderate lethargy (apparent decrease of spontaneous activity); 2, severe lethargy (rare spontaneous movements, but walking after stimulation by the investigator); 3 , unable to walk; 4, dead) [33,34]. When a mouse was no longer able to walk (clinical score 3 ), it was sacrificed for ethical reasons. None of the animals died spontaneously. CSF samples were collected by cisterna magna puncture under isoflurane anesthesia at $12 \mathrm{~h}$ poi. The blood samples were obtained and treated with dipotassium ethylenediaminetetraacetic acid (EDTA $\mathrm{K}_{2}$ ) for the next complete blood count test on an automatic blood cell analyzer (Mindray, BC-1900, Shenzhen, China). The brain samples were collected, frozen in liquid nitrogen instantly, and then stored at $-80^{\circ} \mathrm{C}$ for subsequent experiments. 


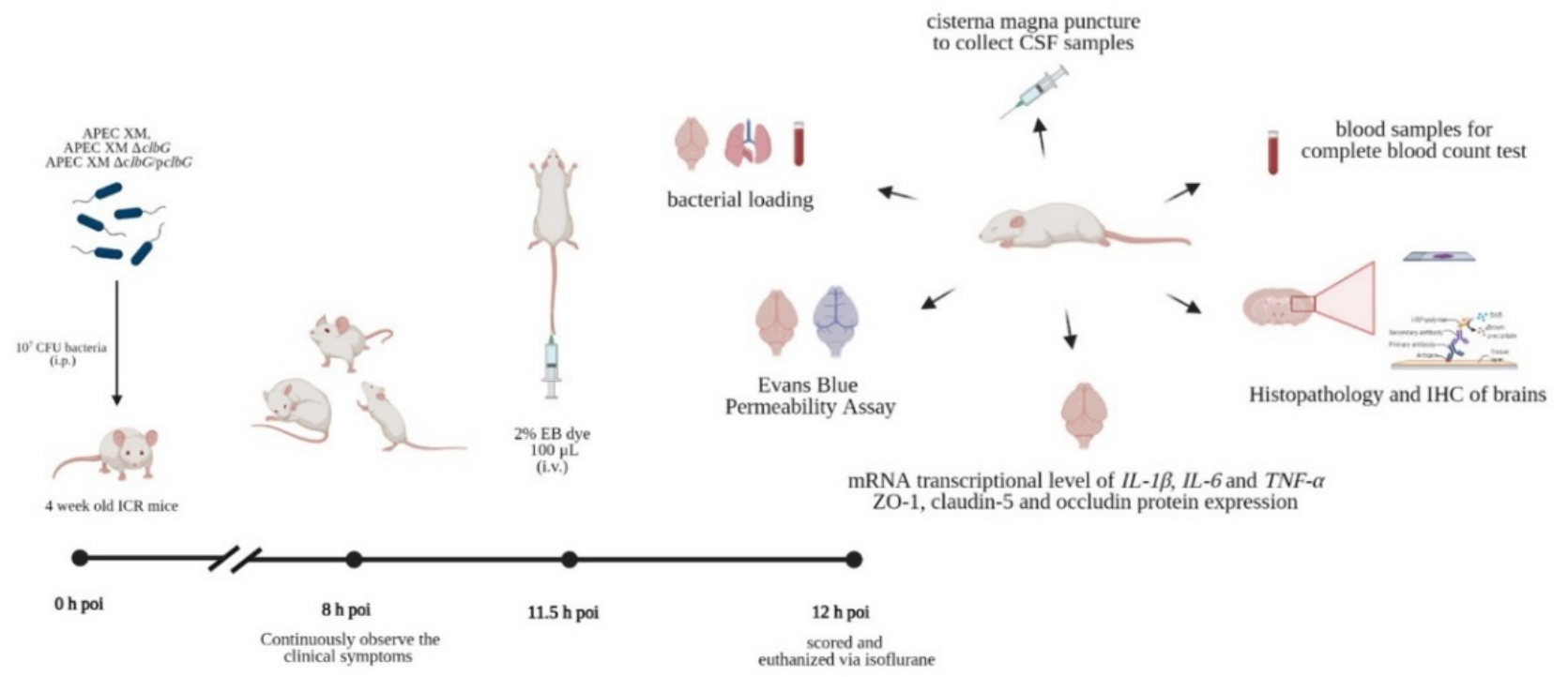

Figure 6. Schematic of mice infection experiments workflow.

\subsection{Evans Blue (EB) Permeability Assay}

For the analysis of changes in BBB permeability in vivo, the mice were injected with $2 \%$ EB $(100 \mu \mathrm{L}$ per mouse) via the tail vein. After $30 \mathrm{~min}$, the mice were anesthetized with isoflurane and then perfused with pro-cool PBS to purge the intravascular EB dye. The brains were frozen in the liquid nitrogen, homogenized in 50\% trichloroacetic, and incubated at $4{ }^{\circ} \mathrm{C}$ for $12 \mathrm{~h}$ [94]. The mixture was centrifuged at $15,000 \times \mathrm{g}$ for $30 \mathrm{~min}$ at $4{ }^{\circ} \mathrm{C}$ to collect the supernatants. The absorbance was measured using a spectrophotometer.

\subsection{Determination of Bacteria Loadings in the Blood, Lung, and Brain}

At $12 \mathrm{~h}$ poi, the tissue samples, including lung, blood, and the right hemisphere of the brain, were collected aseptically and homogenized in $1 \mathrm{~mL}$ sterile pre-cool PBS. Serial dilutions of each sample were plated on MacConkey agar and cultured at $37^{\circ} \mathrm{C}$ for determining CFUs. The bacterial loading was calculated in CFU per gram of brain and lung or per microliter of blood. The PCR test and the agglutination test (K1 and O2) were used to confirm that the colonies were indeed the strain used for infection.

\subsection{Histopathology of the Brain}

At $12 \mathrm{~h}$ poi, the mouse brain was fixed immediately in $4 \%$ paraformaldehyde for routine processing and paraffin embedding. The embedded samples were cut into 3-4 $\mu \mathrm{m}$ sections by an automated microtome (Leica RM2255, Wetzlar, Germany). Prior to hematoxylin and eosin $(\mathrm{H} \& \mathrm{E})$ staining, the sections were deparaffinized to remove the embedding medium and rehydrated at room temperature. The stained slices were observed and photographed by a microscope (Nikon, Eclipse 80i, Tokyo, Japan).

\subsection{Immunohistochemistry of Tight Junction Proteins}

The brain sections were prepared as mentioned above. The sections were treated with $3 \% \mathrm{H}_{2} \mathrm{O}_{2}$ for $10 \mathrm{~min}$ to block endogenous peroxidase activity. Then, they were incubated with citrate buffer for $15 \mathrm{~min}$ at $100{ }^{\circ} \mathrm{C}$ for antigen retrieval. After blocking with bovine serum albumin (BSA) (Cat\#SA1020, Boster Biological Technology, Shanghai, China) at $37{ }^{\circ} \mathrm{C}$ for $1 \mathrm{~h}$, the sections were incubated with primary antibodies at $4{ }^{\circ} \mathrm{C}$ overnight. The primary antibodies used in this study were ZO-1 (1:100; Cat\#61-7300, Invitrogen, Co., Ltd., San Diego, CA, USA), occludin (1:100; Cat\#71-1500, Invitrogen, Co., Ltd., San Diego, CA, USA) and claudin-5 (1:200; Cat\#35-2500, Invitrogen, Co., Ltd., San Diego, CA, USA). Subsequently, the sections were incubated with horseradish peroxidase (HRP) labeling secondary antibody (Cat\#SA1020, Boster Biological Technology, Shanghai, 
China) for $1 \mathrm{~h}$ and visualized by 3,30-diaminobenzidine tetrahydrochloride (DAB; AR1000, Boster Biological Technology, Shanghai, China). The sections were counterstained with hematoxylin, dehydrated, and viewed under a microscope (Leica TCS SP8; Leica Corp., Wetzlar, Germany). Images were analyzed by the soft Image J.

\subsection{IL-1 $\beta, I L-6$, and TNF- $\alpha$ mRNA Expression in Brains}

The total RNAs were extracted from homogenized brains using TRIzol solution (Invitrogen Co., Ltd., San Diego, CA, USA) as the manufacturer's recommendation. RNA purity and quality were measured by nano-drop spectrophotometry. The $900 \mathrm{ng}$ of highquality RNA was converted into cDNA using the PrimeScript RT reagent Kit with gDNA Eraser (Takara, RR047A, Tokyo, Japan). The qRT-PCR reaction was performed on the CFX CONNECT Real-time PCR machine (Bio-Rad, Louisville, KY, USA) using ChamQ SYBR qRT-PCR Master Mix (2×) (Vazyme, Nanjing, China). The primer sequences of $I L-1 \beta, I L-6$, and TNF- $\alpha$ are shown in Table 1 . The amplification program included an initial denaturation at $95^{\circ} \mathrm{C}$ for $10 \mathrm{~min}$, followed by 40 cycles of $95^{\circ} \mathrm{C}$ for $30 \mathrm{~s}, 60^{\circ} \mathrm{C}$ for $30 \mathrm{~s}$, and $72{ }^{\circ} \mathrm{C}$ for $30 \mathrm{~s}$, and a final extension at $72{ }^{\circ} \mathrm{C}$ for $10 \mathrm{~min}$. The relative mRNA expression of each gene was calculated using $2^{-\Delta \Delta \mathrm{Ct}}$ with GAPDH as the internal reference.

\subsection{Western Blotting}

The RIPA lysate buffer (Beyotime Biotech, Nantong, China) was used to extract total proteins from the brain and the bicinchoninic acid protein assay kit (Beyotime, Shanghai, China) was used to determine the concentrations of proteins. The total proteins were run on SDS-PAGE gels and then blotted onto nitrocellulose membranes (Millipore, Billerica, MA, USA) using the BIO-RAD Mini Trans-Blot ${ }^{\circledR}$ System (Bio-Rad, Louisville, KY, USA). The membranes were incubated with $5 \%$ skim milk to reduce nonspecific binding for $1 \mathrm{~h}$ at room temperature. Then, the membranes were incubated overnight at $4{ }^{\circ} \mathrm{C}$ in primary antibodies. The primary antibodies used in this study were ZO-1 (1:1000; Cat\#61-7300, Invitrogen), Occludin (1:500; Cat\#71-1500, Invitrogen), and Claudin-5 (1:50; Cat\#35-2500, Invitrogen) and GAPDH (1:1000; Cat\#2118, Cell Signaling Technology). After the membranes were washed four times with TBST, they were incubated with HRP-conjugated secondary antibodies (all at 1:1000 dilution in $5 \%$ nonfat milk) at room temperature for $1 \mathrm{~h}$. Then, the membranes were visualized using the enhanced chemiluminescence (ECL) reagent (Millipore, Billerica, MA, USA) and the chemiluminescence imaging system (ChemiScope 5300; Clinx Science Instruments, Shanghai, China). The band intensity was analyzed using a chemiluminescence imaging system (ChemiScope 5300; Clinx Science Instruments, Shanghai, China).

\subsection{Statistical Analysis}

Data were analyzed with SPSS 16.0 (SPSS Inc., Chicago, IL, USA) using one-way analysis of variance (ANOVA). Data were represented as mean \pm SEM from triplicate independent experiments. A $p$-valve $<0.05$ was considered to be significant.

Author Contributions: Conceptualization: P.W., X.M. and H.W.; Funding acquisition: H.W., X.M. and J.L. (Jianji Li); Investigation and Project administration: X.M., P.W. and G.Z.; Validation: P.W., J.Z., Y.C., H.Z., J.L. (Jun Li) and J.D.; Writing original draft: P.W.; Writing review and editing: J.L. (Jianji Li), G.Z., P.X., L.C., Q.G., X.M. and H.W. All authors have read and agreed to the published version of the manuscript.

Funding: This work was supported by the National Key R \& D Program under Grant (2017YFD0500203); National Natural Science Foundation of China under Grant (No. 31972651); Postgraduate Research \& Practice Innovation Program of Jiangsu Province under Grant (XKYCX19_127, and x20200691); Priority Academic Program Development of Jiangsu Higher Education Institution under Grant (PAPD); and Top-notch Academic Programs Project of Jiangsu Higher Education Institutions under Grant (TAPP). The funding bodies did not play direct roles in the design of the study and collection, analysis, and interpretation of data and in writing the manuscript. 
Institutional Review Board Statement: The study was approved by Animal Care and Ethics Committee of Yangzhou University (protocol code 202102003, approved on 3 February 2021).

Informed Consent Statement: Not applicable.

Data Availability Statement: The datasets generated and/or analyzed during the current study are not publicly available due to the project is not finished yet but are available from the corresponding author on reasonable request.

Conflicts of Interest: The authors declare no conflict of interest.

\section{References}

1. Nougayrede, J.P.; Homburg, S.; Taieb, F.; Boury, M.; Brzuszkiewicz, E.; Gottschalk, G.; Buchrieser, C.; Hacker, J.; Dobrindt, U.; Oswald, E. Escherichia coli induces DNA double-strand breaks in eukaryotic cells. Science 2006, 313, 848-851. [CrossRef]

2. Putze, J.; Hennequin, C.; Nougayrède, J.P.; Zhang, W.; Homburg, S.; Karch, H.; Bringer, M.A.; Fayolle, C.; Carniel, E.; Rabsch, W.; et al. Genetic structure and distribution of the colibactin genomic island among members of the family Enterobacteriaceae. Infect. Immun. 2009, 77, 4696-4703. [CrossRef]

3. Cuevas-Ramos, G.; Petit, C.R.; Marcq, I.; Boury, M.; Oswald, E.; Nougayrède, J.P. Escherichia coli induces DNA damage in vivo and triggers genomic instability in mammalian cells. Proc. Natl. Acad. Sci. USA 2010, 107, 11537-11542. [CrossRef]

4. Wang, P.; Meng, X.; Li, J.; Chen, Y.; Zhang, D.; Zhong, H.; Xia, P.; Cui, L.; Zhu, G.; Wang, H. Transcriptome profiling of avian pathogenic Escherichia coli and the mouse microvascular endothelial cell line bEnd.3 during interaction. PeerJ 2020, 8, e9172. [CrossRef] [PubMed]

5. Secher, T.; Samba-Louaka, A.; Oswald, E.; Nougayrède, J.P. Escherichia coli producing colibactin triggers premature and transmissible senescence in mammalian cells. PLoS ONE 2013, 8, e77157. [CrossRef] [PubMed]

6. Payros, D.; Secher, T.; Boury, M.; Brehin, C.; Ménard, S.; Salvador-Cartier, C.; Cuevas-Ramos, G.; Watrin, C.; Marcq, I.; Nougayrède, J.P.; et al. Maternally acquired genotoxic Escherichia coli alters offspring's intestinal homeostasis. Gut Microbes 2014, 5, 313-325. [CrossRef] [PubMed]

7. Dalmasso, G.; Cougnoux, A.; Delmas, J.; Darfeuille-Michaud, A.; Bonnet, R. The bacterial genotoxin colibactin promotes colon tumor growth by modifying the tumor microenvironment. Gut Microbes 2014, 5, 675-680. [CrossRef] [PubMed]

8. Cougnoux, A.; Dalmasso, G.; Martinez, R.; Buc, E.; Delmas, J.; Gibold, L.; Sauvanet, P.; Darcha, C.; Déchelotte, P.; Bonnet, M.; et al. Bacterial genotoxin colibactin promotes colon tumour growth by inducing a senescence-associated secretory phenotype. Gut 2014, 63, 1932-1942. [CrossRef]

9. Kaper, J.B.; Nataro, J.P.; Mobley, H.L. Pathogenic Escherichia coli. Nat. Rev. Microbiol. 2004, 2, 123-140. [CrossRef] [PubMed]

10. Kim, K.S. Pathogenesis of bacterial meningitis: From bacteraemia to neuronal injury. Nat. Rev. Neurosci. 2003, 4, 376-385. [CrossRef]

11. Ewers, C.; Antao, E.M.; Diehl, I.; Philipp, H.C.; Wieler, L.H. Intestine and environment of the chicken as reservoirs for extraintestinal pathogenic Escherichia coli strains with zoonotic potential. Appl. Environ. Microbiol. 2009, 75, 184-192. [CrossRef] [PubMed]

12. Moulin-Schouleur, M.; Reperant, M.; Laurent, S.; Bree, A.; Mignon-Grasteau, S.; Germon, P.; Rasschaert, D.; Schouler, C. Extraintestinal pathogenic Escherichia coli strains of avian and human origin: Link between phylogenetic relationships and common virulence patterns. J. Clin. Microbiol. 2007, 45, 3366-3376. [CrossRef]

13. Johnson, J.R.; Oswald, E.; O’Bryan, T.T.; Kuskowski, M.A.; Spanjaard, L. Phylogenetic distribution of virulence-associated genes among Escherichia coli isolates associated with neonatal bacterial meningitis in the Netherlands. J. Infect. Dis. 2002, 185, 774-784. [CrossRef]

14. Bonacorsi, S.; Bingen, E. Molecular epidemiology of Escherichia coli causing neonatal meningitis. Int. J. Med. Microbiol. 2005, 295, 373-381. [CrossRef]

15. Saha, O.; Hoque, M.N.; Islam, O.K.; Rahaman, M.M.; Sultana, M.; Hossain, M.A. Multidrug-resistant Avian Pathogenic Escherichia coli strains and association of their virulence genes in Bangladesh. Microorganisms 2020, 8, 1135. [CrossRef]

16. Rahayuningtyas, I.; Indrawati, A.; Wibawan, I.W.T.; Palupi, M.F.; Istiyaningsih, I. Phylogenetic group determination and plasmid virulence gene profiles of colistin-resistant Escherichia coli originated from the broiler meat supply chain in Bogor, Indonesia. Vet. World 2020, 13, 1807-1814. [CrossRef]

17. Nielsen, D.W.; Ricker, N.; Barbieri, N.L.; Allen, H.K.; Nolan, L.K.; Logue, C.M. Outer membrane protein A (OmpA) of extraintestinal pathogenic Escherichia coli. BMC Res. Notes 2020, 13, 51. [CrossRef]

18. Mitchell, N.M.; Johnson, J.R.; Johnston, B.; Curtiss, R., 3rd; Mellata, M. Zoonotic potential of Escherichia coli isolates from retail chicken meat products and eggs. Appl. Environ. Microbiol. 2015, 81, 1177-1187. [CrossRef]

19. Krishnan, S.; Chang, A.C.; Hodges, J.; Couraud, P.O.; Romero, I.A.; Weksler, B.; Nicholson, B.A.; Nolan, L.K.; Prasadarao, N.V. Serotype $\mathrm{O} 18$ avian pathogenic and neonatal meningitis Escherichia coli strains employ similar pathogenic strategies for the onset of meningitis. Virulence 2015, 6, 777-786. [CrossRef] 
20. Tivendale, K.A.; Logue, C.M.; Kariyawasam, S.; Jordan, D.; Hussein, A.; Li, G.; Wannemuehler, Y.; Nolan, L.K. Avian-pathogenic Escherichia coli strains are similar to neonatal meningitis E. coli strains and are able to cause meningitis in the rat model of human disease. Infect. Immun. 2010, 78, 3412-3419. [CrossRef]

21. Rodriguez-Siek, K.E.; Giddings, C.W.; Doetkott, C.; Johnson, T.J.; Fakhr, M.K.; Nolan, L.K. Comparison of Escherichia coli isolates implicated in human urinary tract infection and avian colibacillosis. J. Gen. Microbiol. 2005, 151, 2097-2110. [CrossRef]

22. Johnson, T.J.; Kariyawasam, S.; Wannemuehler, Y.; Mangiamele, P.; Johnson, S.J.; Doetkott, C.; Skyberg, J.A.; Lynne, A.M.; Johnson, J.R.; Nolan, L.K. The genome sequence of avian pathogenic Escherichia coli strain O1:K1:H7 shares strong similarities with human extraintestinal pathogenic E. coli genomes. J. Bacteriol. 2007, 189, 3228-3236. [CrossRef] [PubMed]

23. Nowrouzian, F.L.; Oswald, E. Escherichia coli strains with the capacity for long-term persistence in the bowel microbiota carry the potentially genotoxic $p k s$ island. Microb. Pathog. 2012, 53, 180-182. [CrossRef] [PubMed]

24. Johnson, J.R.; Johnston, B.; Kuskowski, M.A.; Nougayrede, J.P.; Oswald, E. Molecular epidemiology and phylogenetic distribution of the Escherichia coli pks genomic island. J. Clin. Microbiol. 2008, 46, 3906-3911. [CrossRef] [PubMed]

25. Dubois, D.; Delmas, J.; Cady, A.; Robin, F.; Sivignon, A.; Oswald, E.; Bonnet, R. Cyclomodulins in urosepsis strains of Escherichia coli. J. Clin. Microbiol. 2010, 48, 2122-2129. [CrossRef]

26. McCarthy, A.J.; Martin, P.; Cloup, E.; Stabler, R.A.; Oswald, E.; Taylor, P.W. The Genotoxin Colibactin Is a Determinant of Virulence in Escherichia coli K1 Experimental Neonatal Systemic Infection. Infect. Immun. 2015, 83, 3704-3711. [CrossRef]

27. Wijetunge, D.S.; Gongati, S.; DebRoy, C.; Kim, K.S.; Couraud, P.O.; Romero, I.A.; Weksler, B.; Kariyawasam, S. Characterizing the pathotype of neonatal meningitis causing Escherichia coli (NMEC). BMC Microbiol. 2015, 15, 211. [CrossRef]

28. Logue, C.M.; Doetkott, C.; Mangiamele, P.; Wannemuehler, Y.M.; Johnson, T.J.; Tivendale, K.A.; Li, G.; Sherwood, J.S.; Nolan, L.K. Genotypic and phenotypic traits that distinguish neonatal meningitis-associated Escherichia coli from fecal E. coli isolates of healthy human hosts. Appl. Environ. Microbiol. 2012, 78, 5824-5830. [CrossRef]

29. Marcq, I.; Martin, P.; Payros, D.; Cuevas-Ramos, G.; Boury, M.; Watrin, C.; Nougayrede, J.P.; Olier, M.; Oswald, E. The genotoxin colibactin exacerbates lymphopenia and decreases survival rate in mice infected with septicemic Escherichia coli. J. Infect. Dis. 2014, 210, 285-294. [CrossRef]

30. Lu, M.C.; Chen, Y.T.; Chiang, M.K.; Wang, Y.C.; Hsiao, P.Y.; Huang, Y.J.; Lin, C.T.; Cheng, C.C.; Liang, C.L.; Lai, Y.C. Colibactin Contributes to the Hypervirulence of pks(+) K1 CC23 Klebsiella pneumoniae in Mouse Meningitis Infections. Front. Cell. Infect. Microbiol. 2017, 7, 103. [CrossRef] [PubMed]

31. Healy, A.R.; Wernke, K.M.; Kim, C.S.; Lees, N.R.; Crawford, J.M.; Herzon, S.B. Synthesis and reactivity of precolibactin 886. Nat. Chem. 2019, 11, 890-898. [CrossRef] [PubMed]

32. Brachmann, A.O.; Garcie, C.; Wu, V.; Martin, P.; Ueoka, R.; Oswald, E.; Piel, J. Colibactin biosynthesis and biological activity depend on the rare aminomalonyl polyketide precursor. Chem. Commun. 2015, 51, 13138-13141. [CrossRef] [PubMed]

33. Gerber, J.; Raivich, G.; Wellmer, A.; Noeske, C.; Kunst, T.; Werner, A.; Brück, W.; Nau, R. A mouse model of Streptococcus pneumoniae meningitis mimicking several features of human disease. Acta Neuropathol. 2001, 101, 499-508. [CrossRef]

34. Ribes, S.; Regen, T.; Meister, T.; Tauber, S.C.; Schütze, S.; Mildner, A.; Mack, M.; Hanisch, U.K.; Nau, R. Resistance of the brain to Escherichia coli K1 infection depends on MyD88 signaling and the contribution of neutrophils and monocytes. Infect. Immun. 2013, 81, 1810-1819. [CrossRef]

35. Tauzin, M.; Ouldali, N.; Levy, C.; Bechet, S.; Cohen, R.; Caeymaex, L. Combination therapy with ciprofloxacin and third-generation cephalosporin versus third-generation cephalosporin monotherapy in Escherichia coli meningitis in infants: A multicentre propensity score-matched observational study. Clin. Microbiol. Infect. Off. Publ. Eur. Soc. Clin. Microbiol. Infect. Dis. 2019, 25, 1006-1012. [CrossRef]

36. Kim, K.S. Acute bacterial meningitis in infants and children. Lancet Infect. Dis. 2010, 10, 32-42. [CrossRef]

37. Kim, K.S. Human meningitis-associated Escherichia coli. EcoSal Plus 2016, 7. [CrossRef] [PubMed]

38. Ewers, C.; Li, G.; Wilking, H.; Kiessling, S.; Alt, K.; Antao, E.M.; Laturnus, C.; Diehl, I.; Glodde, S.; Homeier, T.; et al. Avian pathogenic, uropathogenic, and newborn meningitis-causing Escherichia coli: How closely related are they? Int. J. Med. Microbiol. 2007, 297, 163-176. [CrossRef]

39. Martin, O.C.B.; Frisan, T.; Mihaljevic, B. Bacterial Genotoxins as the Interphase Between DNA Damage and Immune Response. In Microbial Toxins; Stiles, B., Alape-Girón, A., Dubreuil, J.D., Mandal, M., Gopalakrishnakone, P., Eds.; Springer: Dordrecht, The Netherlands, 2018; pp. 383-402.

40. Zha, L.; Wilson, M.R.; Brotherton, C.A.; Balskus, E.P. Characterization of Polyketide Synthase Machinery from the pks Island Facilitates Isolation of a Candidate Precolibactin. ACS Chem. Biol. 2016, 11, 1287-1295. [CrossRef]

41. Dietzman, D.E.; Fischer, G.W.; Schoenknecht, F.D. Neonatal Escherichia coli septicemia-bacterial counts in blood. J. Pediatrics 1974, 85, 128-130. [CrossRef]

42. Kim, K.S.; Itabashi, H.; Gemski, P.; Sadoff, J.; Warren, R.L.; Cross, A.S. The K1 capsule is the critical determinant in the development of Escherichia coli meningitis in the rat. J. Clin. Investig. 1992, 90, 897-905. [CrossRef]

43. Secher, T.; Brehin, C.; Oswald, E. Early settlers: Which, E. coli strains do you not want at birth? Am. J. Physiol. Gastrointest. Liver Physiol. 2016, 311, G123-G129. [CrossRef] [PubMed]

44. Secher, T.; Payros, D.; Brehin, C.; Boury, M.; Watrin, C.; Gillet, M.; Bernard-Cadenat, I.; Menard, S.; Theodorou, V.; Saoudi, A.; et al. Oral tolerance failure upon neonatal gut colonization with Escherichia coli producing the genotoxin colibactin. Infect. Immun. 2015, 83, 2420-2429. [CrossRef] 
45. Pfister, H.W.; Fontana, A.; Tauber, M.G.; Tomasz, A.; Scheld, W.M. Mechanisms of brain injury in bacterial meningitis: Workshop summary. Clin. Infect. Dis. Off. Publ. Infect. Dis. Soc. Am. 1994, 19, 463-479. [CrossRef]

46. Nau, R.; Soto, A.; Bruck, W. Apoptosis of neurons in the dentate gyrus in humans suffering from bacterial meningitis. J. Neuropathol. Exp. Neurol. 1999, 58, 265-274. [CrossRef] [PubMed]

47. Scheld, W.M.; Koedel, U.; Nathan, B.; Pfister, H.W. Pathophysiology of bacterial meningitis: Mechanism(s) of neuronal injury. J. Infect. Dis. 2002, 186 (Suppl. 2), S225-S233. [CrossRef]

48. Zhang, C. The role of inflammatory cytokines in endothelial dysfunction. Basic Res. Cardiol. 2008, 103, 398-406. [CrossRef] [PubMed]

49. Smith, J.A.; Das, A.; Ray, S.K.; Banik, N.L. Role of pro-inflammatory cytokines released from microglia in neurodegenerative diseases. Brain Res. Bull. 2012, 87, 10-20. [CrossRef]

50. Linnerbauer, M.; Wheeler, M.A.; Quintana, F.J. Astrocyte Crosstalk in CNS Inflammation. Neuron 2020, 108, 608-622. [CrossRef]

51. Winkler, F.; Koedel, U.; Kastenbauer, S.; Pfister, H.W. Differential expression of nitric oxide synthases in bacterial meningitis: Role of the inducible isoform for blood-brain barrier breakdown. J. Infect. Dis. 2001, 183, 1749-1759. [CrossRef]

52. Koedel, U.; Paul, R.; Winkler, F.; Kastenbauer, S.; Huang, P.L.; Pfister, H.W. Lack of endothelial nitric oxide synthase aggravates murine pneumococcal meningitis. J. Neuropathol. Exp. Neurol. 2001, 60, 1041-1050. [CrossRef] [PubMed]

53. Li, X.; Zhang, Z.; Chang, X.; Wang, X.; Hu, J.; Lin, Q.; Jia, Y.; Yang, X.; Wang, X. Disruption of blood-brain barrier by an Escherichia coli isolated from canine septicemia and meningoencephalitis. Comp. Immunol. Microbiol. Infect. Dis. 2019, 63, 44-50. [CrossRef]

54. Eisenhauer, P.B.; Jacewicz, M.S.; Conn, K.J.; Koul, O.; Wells, J.M.; Fine, R.E.; Newburg, D.S. Escherichia coli Shiga toxin 1 and TNF-alpha induce cytokine release by human cerebral microvascular endothelial cells. Microb. Pathog. 2004, 36, 189-196. [CrossRef] [PubMed]

55. Krishnan, S.; Chang, A.C.; Stoltz, B.M.; Prasadarao, N.V. Escherichia coli K1 modulates peroxisome proliferator-activated receptor gamma and glucose transporter 1 at the blood-brain barrier in neonatal meningitis. J. Infect. Dis. 2016, 214, 1092-1104. [CrossRef]

56. Lemon, J.K.; Miller, M.R.; Weiser, J.N. Sensing of interleukin-1 cytokines during Streptococcus pneumoniae colonization contributes to macrophage recruitment and bacterial clearance. Infect. Immun. 2015, 83, 3204-3212. [CrossRef]

57. Guo, H.L.; Shi, F.D.; Zhou, Q.; Liu, Q.Y.; Wang, Y.X.; Song, Y.; Wu, Z.S.; Shi, Y.H.; Zhang, L.; Xu, K.Z.; et al. Interleukin-1beta protection against experimental sepsis in mice. Inflammation 2021, 44, 358-370. [CrossRef]

58. Merrill, J.E.; Benveniste, E.N. Cytokines in inflammatory brain lesions: Helpful and harmful. Trends Neurosci. 1996, 19, 331-338. [CrossRef]

59. Benveniste, E.N. Cytokines: Influence on glial cell gene expression and function. Chem. Immunol. 1992, 52, 106-153. [PubMed]

60. Furth, A.M.V.; Roord, J.J.; Furth, R.V. Roles of proinflammatory and anti-inflammatory cytokines in pathophysiology of bacterial meningitis and effect of adjunctive therapy-15. Infect. Immun. 1996, 64, 4883-4890. [CrossRef]

61. Wellmer, A.; Gerber, J.; Ragheb, J.; Zysk, G.; Kunst, T.; Smirnov, A.; Bruck, W.; Nau, R. Effect of deficiency of tumor necrosis factor alpha or both of its receptors on Streptococcus pneumoniae central nervous system infection and peritonitis. Infect. Immun. 2001, 69, 6881-6886. [CrossRef]

62. Damas, P.; Ledoux, D.; Nys, M.; Vrindts, Y.; De Groote, D.; Franchimont, P.; Lamy, M. Cytokine serum level during severe sepsis in human IL-6 as a marker of severity. Ann. Surg. 1992, 215, 356-362. [CrossRef]

63. Voirin, A.C.; Perek, N.; Roche, F. Inflammatory stress induced by a combination of cytokines (IL-6, IL-17, TNF-alpha) leads to a loss of integrity on bEnd.3 endothelial cells in vitro BBB model. Brain Res. 2020, 1730, 146647. [CrossRef] [PubMed]

64. Fang, M.; Zhong, W.H.; Song, W.L.; Deng, Y.Y.; Yang, D.M.; Xiong, B.; Zeng, H.K.; Wang, H.D. Ulinastatin ameliorates pulmonary capillary endothelial permeability induced by sepsis through protection of tight junctions via inhibition of TNF-alpha and related pathways. Front. Pharmacol. 2018, 9, 823. [CrossRef]

65. Zhang, Y.; Ding, X.; Miao, C.; Chen, J. Propofol attenuated TNF- $\alpha$-modulated occludin expression by inhibiting Hif$1 \alpha /$ VEGF/VEGFR-2/ERK signaling pathway in hCMEC/D3 cells. BMC Anesthesiol. 2019, 19, 127. [CrossRef]

66. Clark, P.R.; Kim, R.K.; Pober, J.S.; Kluger, M.S. Tumor necrosis factor disrupts claudin-5 endothelial tight junction barriers in two distinct NF-kappaB-dependent phases. PLoS ONE 2015, 10, e0120075. [CrossRef] [PubMed]

67. Maeda, H.; Hashimoto, K.; Go, H.; Miyazaki, K.; Sato, M.; Kawasaki, Y.; Momoi, N.; Hosoya, M. Towards the development of a human in vitro model of the blood-brain barrier for virus-associated acute encephalopathy: Assessment of the time- and concentration-dependent effects of TNF-alpha on paracellular tightness. Exp. Brain Res. 2021, 239, 451-461. [CrossRef]

68. Desai, T.R.; Leeper, N.J.; Hynes, K.L.; Gewertz, B.L. Interleukin-6 causes endothelial barrier dysfunction via the protein kinase C pathway. J. Surg. Res. 2002, 104, 118-123. [CrossRef]

69. Al-Obaidi, M.M.J.; Desa, M.N.M. Mechanisms of blood brain barrier disruption by different types of bacteria, and bacterial-host interactions facilitate the bacterial pathogen invading the brain. Cell. Mol. Neurobiol. 2018, 38, 1349-1368. [CrossRef] [PubMed]

70. Bauer, H.-C.; Krizbai, I.A.; Bauer, H.; Traweger, A. "You Shall Not Pass"-Tight junctions of the blood brain barrier. Front. Neurosci. 2014, 8, 392. [CrossRef]

71. Luissint, A.C.; Artus, C.; Glacial, F.; Ganeshamoorthy, K.; Couraud, P.O. Tight junctions at the blood brain barrier: Physiological architecture and disease-associated dysregulation. Fluids Barriers CNS 2012, 9, 23. [CrossRef]

72. Kim, B.J.; Hancock, B.M.; Bermudez, A.; Del Cid, N.; Reyes, E.; van Sorge, N.M.; Lauth, X.; Smurthwaite, C.A.; Hilton, B.J.; Stotland, A.; et al. Bacterial induction of Snail1 contributes to blood-brain barrier disruption. J. Clin. Investig. 2015, 125, 2473-2483. [CrossRef] 
73. McLoughlin, A.; Rochfort, K.D.; McDonnell, C.J.; Kerrigan, S.W.; Cummins, P.M. Staphylococcus aureus-mediated blood-Brain barrier injury: An in vitro human brain microvascular endothelial cell model. Cell. Microbiol. 2017, 19, e12664. [CrossRef] [PubMed]

74. Kim, B.J.; Bee, O.B.; McDonagh, M.A.; Stebbins, M.J.; Palecek, S.P.; Doran, K.S.; Shusta, E.V. Modeling Group B Streptococcus and blood-brain barrier interaction by using induced pluripotent stem cell-derived brain endothelial cells. mSphere 2017, 2, e00398-17. [CrossRef] [PubMed]

75. Martins Gomes, S.F.; Westermann, A.J.; Sauerwein, T.; Hertlein, T.; Forstner, K.U.; Ohlsen, K.; Metzger, M.; Shusta, E.V.; Kim, B.J.; Appelt-Menzel, A.; et al. Induced pluripotent stem cell-derived brain endothelial cells as a cellular model to study Neisseria meningitidis infection. Front. Microbiol. 2019, 10, 1181. [CrossRef]

76. Tenenbaum, T.; Matalon, D.; Adam, R.; Seibt, A.; Wewer, C.; Schwerk, C.; Galla, H.J.; Schroten, H. Dexamethasone prevents alteration of tight junction-associated proteins and barrier function in porcine choroid plexus epithelial cells after infection with Streptococcus suis in vitro. Brain Res. 2008, 1229, 1-17. [CrossRef] [PubMed]

77. Wang, W.; Cai, M.; Hu, J.; Zhang, Z.; Wang, X.; Chang, X.; Zhang, F.; Guo, C.; Wang, X. Mechanism of blood-brain barrier disruption by an Escherichia coli from lambs with severe diarrhea and meningoencephalitis. Microb. Pathog. 2020, 147, 104288. [CrossRef]

78. Stevenson, B.R.; Siliciano, J.D.; Mooseker, M.S.; Goodenough, D.A. Identification of ZO-1: A high molecular weight polypeptide associated with the tight junction (zonula occludens) in a variety of epithelia. J. Cell Biol. 1986, 103, 755-766. [CrossRef]

79. Stamatovic, S.M.; Sladojevic, N.; Keep, R.F.; Andjelkovic, A.V. PDCD10 (CCM3) regulates brain endothelial barrier integrity in cerebral cavernous malformation type 3: Role of CCM3-ERK1/2-cortactin cross-talk. Acta Neuropathol. 2015, 130, 731-750. [CrossRef]

80. Bauer, A.T.; Burgers, H.F.; Rabie, T.; Marti, H.H. Matrix metalloproteinase-9 mediates hypoxia-induced vascular leakage in the brain via tight junction rearrangement. J. Cereb. Blood Flow Metab. 2010, 30, 837-848. [CrossRef]

81. DeMaio, L.; Rouhanizadeh, M.; Reddy, S.; Sevanian, A.; Hwang, J.; Hsiai, T.K. Oxidized phospholipids mediate occludin expression and phosphorylation in vascular endothelial cells. Am. J. Physiol. Heart Circ. Physiol. 2006, 290, H674-H683. [CrossRef]

82. Kabra, R.; Knight, K.K.; Zhou, R.; Snyder, P.M. Nedd4-2 induces endocytosis and degradation of proteolytically cleaved epithelial $\mathrm{Na}+$ channels. J. Biol. Chem. 2008, 283, 6033-6039. [CrossRef]

83. Ni, Y.; Teng, T.; Li, R.; Simonyi, A.; Sun, G.Y.; Lee, J.C. TNFalpha alters occludin and cerebral endothelial permeability: Role of p38MAPK. PLoS ONE 2017, 12, e0170346. [CrossRef]

84. Morita, K.; Sasaki, H.; Furuse, M.; Tsukita, S. Endothelial claudin: Claudin-5/TMVCF constitutes tight junction strands in endothelial cells. J. Cell Biol. 1999, 147, 185-194. [CrossRef] [PubMed]

85. Virgintino, D.; Errede, M.; Robertson, D.; Capobianco, C.; Girolamo, F.; Vimercati, A.; Bertossi, M.; Roncali, L. Immunolocalization of tight junction proteins in the adult and developing human brain. Histochem. Cell Biol. 2004, 122, 51-59. [CrossRef]

86. Wen, H.; Watry, D.D.; Marcondes, M.C.; Fox, H.S. Selective decrease in paracellular conductance of tight junctions: Role of the first extracellular domain of claudin-5. Mol. Cell. Biol. 2004, 24, 8408-8417. [CrossRef]

87. Papadopoulos, M.C.; Saadoun, S.; Binder, D.K.; Manley, G.T.; Krishna, S.; Verkman, A.S. Molecular mechanisms of brain tumor edema. Neuroscience 2004, 129, 1011-1020. [CrossRef] [PubMed]

88. Neuhaus, W.; Piontek, A.; Protze, J.; Eichner, M.; Mahringer, A.; Subileau, E.A.; Lee, I.M.; Schulzke, J.D.; Krause, G.; Piontek, J. Reversible opening of the blood-brain barrier by claudin-5-binding variants of Clostridium perfringens enterotoxin's claudinbinding domain. Biomaterials 2018, 161, 129-143. [CrossRef]

89. Platania, C.B.M.; Lazzara, F.; Fidilio, A.; Fresta, C.G.; Conti, F.; Giurdanella, G.; Leggio, G.M.; Salomone, S.; Drago, F.; Bucolo, C. Blood-retinal barrier protection against high glucose damage: The role of P2X7 receptor. Biochem. Pharmacol. 2019, 168, 249-258. [CrossRef]

90. Datsenko, K.A.; Wanner, B.L. One-step inactivation of chromosomal genes in Escherichia coli K-12 using PCR products. Proc. Natl. Acad. Sci. USA 2000, 97, 6640-6645. [CrossRef] [PubMed]

91. Martin, P.; Marcq, I.; Magistro, G.; Penary, M.; Oswald, E. Interplay between Siderophores and Colibactin Genotoxin Biosynthetic Pathways in Escherichia coli. PLoS Pathog. 2013, 9, e1003437. [CrossRef]

92. Solovjeva, L.; Firsanov, D.; Pleskach, N.; Svetlova, M. Immunofluorescence Analysis of $\gamma$-H2AX Foci in Mammalian Fibroblasts at Different Phases of the Cell Cycle. Methods Mol. Biol. 2017, 1644, 187-194. [CrossRef] [PubMed]

93. Hejair, H.M.A.; Ma, J.; Zhu, Y.; Sun, M.; Dong, W.; Zhang, Y.; Pan, Z.; Zhang, W.; Yao, H. Role of outer membrane protein T in pathogenicity of avian pathogenic Escherichia coli. Res. Vet. Sci. 2017, 115, 109-116. [CrossRef]

94. Manaenko, A.; Chen, H.; Kammer, J.; Zhang, J.H.; Tang, J. Comparison Evans Blue injection routes: Intravenous versus intraperitoneal, for measurement of blood-brain barrier in a mice hemorrhage model. J. Neurosci. Methods 2011, 195, 206-210. [CrossRef] 